\title{
Watershed-Based Planning for Murrells Inlet: Source Assessment of Fecal Bacteria Using Volunteer and Shellfish Sanitation Program Data
}

\author{
Susan Libes ${ }^{1}$, Heather Young ${ }^{2}$, Daniel Newquist ${ }^{3}$, and Sue Sledz ${ }^{4}$
}

\begin{abstract}
AUTHORS: ${ }^{1}$ Professor of Marine Science and Chemistry, Coastal Carolina University, P.O. Box 261954, Conway, South Carolina 29528-6054, USA. ${ }^{2}$ Former Research Grant Specialist, Coastal Carolina University, P.O. Box 261954, Conway, South Carolina 29528-6054, USA. ${ }^{3}$ Section 208 Coordinator, Waccamaw Council of Governments, Georgetown, South Carolina 29440, USA. ${ }^{4}$ Former Executive Director, Murrells Inlet 2020, Murrells Inlet, South Carolina 29576, USA.
\end{abstract}

\begin{abstract}
A watershed-based plan was recently developed for Murrells Inlet, a moderately tidal, euhaline estuary located on the northern coast of South Carolina. One of the goals of this planning effort was to collate and analyze existing data to refine assessments of the sources of fecal coliform detected by SC DHEC's shellfish monitoring program. Coastal Carolina University's Waccamaw Watershed Academy (WWA) was engaged to lead this data analysis effort. The most important sources identified were urbanized wildlife and canines. Results from the data analyses were used to prioritize subwatersheds for remediation. This has led to proposed strategies that focus on interception and treatment of stormwater runoff as well as volume reduction, dredging of tidal creek sediments, and outreach education for pet waste control.
\end{abstract}

\section{INTRODUCTION}

Murrells Inlet is a moderately tidal, euhaline estuary located on the northern coast of South Carolina (Figure 1). The watershed encompasses 3748 hectares with 2560 hectares comprised of land draining into the estuary. The remaining area consists of open water, intertidal mudflats and marsh habitat. SC DHEC estimates that 1258 hectares are suitable habitat for production of shellfish (SC DHEC 2014). Shellfish harvesting is approved in $71 \%$ of this area and administratively classified as "Prohibited" in 5\% due to the presence of marinas. In the remaining $24 \%$, harvesting is restricted due to elevated fecal coliform levels reported from monitoring conducted by SC DHEC under their shellfish sanitation program.

TMDL's are a tool under the federal Clean Water Act to help bring polluted waters into compliance with water quality standards, thereby enabling designated uses, such as shellfishing, to be supported. A Total Maximum Daily Load (TMDL) was approved by SC DHEC in 2005 to address these long-standing fecal coliform impairments (SC DHEC 2005). To implement the TMDL, a watershed plan was developed in 2014 that specifies prioritized actions to reduce loading of fecal bacteria into Murrells Inlet. These were developed from a detailed review of land use, watershed dynamics, regulatory controls, previous efforts at source assessment, and a new set of statistical analyses performed on SC DHEC's shellfish monitoring data and the data collected by the Murrells Inlet Volunteer Water Quality Monitoring (VM) program. Details on the review of land use, including a change analyses, can be found in Fuss et al. (2014), watershed dynamics in Williams et al. (2014), and the regulatory context in Newquist et al. (2014).

In this paper, we review previous microbial source tracking (MST) work and discuss the new statistical analyses that were performed to prioritize locations and strategies for remediation. These analyses used SC DHEC and VM monitoring data to identify locations of the most significant fecal bacteria sources and transport pathways. This information comprised Element D.I and Appendix D in the watershed plan (Newquist 2014). The plan was approved by SC DHEC in 2014 and used by the stormwater managers in Horry and Georgetown Counties to obtain funding from the USEPA 319 program to support implementation of stormwater treatment practices in the subwatersheds prioritized by the statistical analyses.

\section{BACKGROUND AND RELATED WORK}

Regulatory Context. TMDL's generally specify a quantified load reduction that once implemented will bring the impaired waters into regulatory compliance with water quality standards. Implementation of TMDL's had been voluntary until the advent of the Municipal Separate Storm Sewer System (MS4) permit program which now requires permitees to take actions to bring waterbodies in their jurisdictions into compliance with water quality standards.

TMDLs must be developed by the states and approved by USEPA within 13 years of initial listing of a site on 
the 303(d) list of impaired waterbodies. This listing is a consequence of frequent contraventions of water quality standards. In the case of shellfish waters, the standard is based on the National Shellfish Sanitation Program (NSSP) requirements that are used to determine if a shellfish bed can be approved for shellfish harvesting, i.e., the geometric mean (geomean) of fecal coliform concentrations is less than 14 MPN/100 $\mathrm{mL}$ and the estimated (Est.) $90^{\text {th }}$ percentile is less than $43 \mathrm{MPN} / 100 \mathrm{~mL}$ (US FDA 2009) ${ }^{1}$. SC DHEC uses three years of data to generate these statistics in which samples are collected approximately once per month to generate a minimum of 30 and a maximum of 36 samples for each monitoring site.

Sampling dates are randomly selected with respect to tidal stage and weather. Sampling sites in Murrells Inlet were originally selected in a stratified random manner. But due to increasingly limited resources, SC DHEC has adjusted their sampling over the decades to more closely define boundaries of closed shellfish beds, thereby minimizing the total area closed to shellfishing. This strategy has led to a decline in the number of relatively "clean" sites now being monitored.

In 2008, the USEPA recommended a watershedbased framework for TMDL development as opposed to using a single-segment approach. The goal is to provide a framework for more efficiently addressing the maximum number of impairments in a scientifically defensible manner (USEPA 2008). The original TMDL approved for Murrells Inlet encompassed eight sites that were determined to be influenced by drainage from three subwatersheds. Over successive 303(d) reporting periods, SC DHEC increased the number of monitoring sites covered by the fecal coliform TMDL to 20, with some of the additional sites having become impaired after 2005 (Table 1). Most of these additional sites are influenced by drainage from subwatersheds other than the three for which load reductions were specified in the TMDL approved in 2005. Those load reductions were approximately 71 to $81 \%$. They were determined by modelling monitoring data collected from 2001 to 2004 . The host animal source assessment was qualitative and concluded that wildlife was the most significant source. The TMDL approved in 2005 did not recommend any means by which the load reductions could be attained.

Microbial Source Tracking Investigations. Efforts have been undertaken to identify sources and transport pathways of the fecal bacteria in Murrells Inlet. These have included: (1) assessment efforts conducted from 2005 to 2006 associated with the development of a Special Area Management Plan (SAMP) by SC DHEC Ocean and Coastal Resource Management (OCRM) (Bennett 2007); (2) volunteer water

\footnotetext{
${ }^{1}$ These are the Class SFH (shellfish harvesting) water quality criteria specified in SC R.61-68. Concentrations are reported as Most Probable Number (MPN) per $100 \mathrm{~mL}$ of sample. The Est. $90^{\text {th }}$ percentile is used to minimize the impact of rare random pollution events that could skew the $90^{\text {th }}$ percentile because of a few high MPN values.
}

Table 1. Number of sites in and within the Murrells Inlet TMDL area as reported by SC DHEC in its biennial 303(d) listings. ${ }^{2}$

\begin{tabular}{c|c|c}
\hline 303(d) list & Data years & Number of TMDL sites \\
\hline 2006 & 2000 to 2004 & $(8)$ \\
\hline 2008 & 2002 to 2006 & 9 \\
\hline 2010 & 2004 to 2008 & 17 \\
\hline 2012 & 2006 to 2010 & 20 \\
\hline 2014 & 2008 to 2012 & 20 \\
\hline
\end{tabular}

quality monitoring initiated in 2008 (Libes et al. 2012); (3) microbial source tracking using multiple antibiotic resistance and GIS modeling (Kelsey et al. 2003; Kelsey et al. 2004); and (4) spatial surveys conducted by SC DHEC, Georgetown County, Coastal Carolina University, and the volunteer water quality monitors (all since 2010). The latter included measurement of fecal bacteria in sediments (Anderson and Greoski, 2010). A multiple tracer study performed in the northern end of Murrells Inlet using genotypic assays was completed in 2013 and hence was not available for inclusion in the watershed plan (Sturgeon et al. 2014).

The work of Kelsey et al. (2003 and 2004) supported stormwater transport as the major pathway by which fecal coliforms are being conveyed into Murrells Inlet. Microbial antibiotic resistance measurements suggested that the major host animal sources were wildlife. The work of Sturgeon et al. (2014), conducted on samples collected from the north end of Murrells Inlet in 2012 and 2013, confirmed that humans are not a significant source, but that canines, inclusive of coyotes, and aquatic birds were significant sources.

The work of Bennett (2007), which was designed to assess the efficacy of two stormwater treatment practices, documented elevated levels of fecal bacteria at nearby control sites. These were located in two tributary streams discharging into Murrells Inlet. A volunteer water quality monitoring program was then instituted to further investigate the role of small tributary streams as a significant source of fecal bacteria to the creeks of Murrells Inlet.

The volunteer monitors sample sites located at the terminus of six small tributary streams and at two shorebased sites in the Inlet proper, with one in the north (Horry County) and one in south (Georgetown County). See squares in Figure 1 for sampling site locations. Sampling has been conducted bimonthly since July 2009 for fecal bacteria (E. coli and total coliform using Micrology's Easygel ${ }^{\mathrm{TM}}$ dual confirmation media). This monitoring documented that several of the tributary streams frequently had high levels of fecal bacteria (Table 2). Fecal bacteria were

\footnotetext{
${ }^{2}$ This information is available at: http://www.scdhec.gov/ HomeAndEnvironment/Water/ImpairedWaters/Overview/\#4. Although the TMDL sites are not on the 303(d) list, SC DHEC provides an additional table.
} 


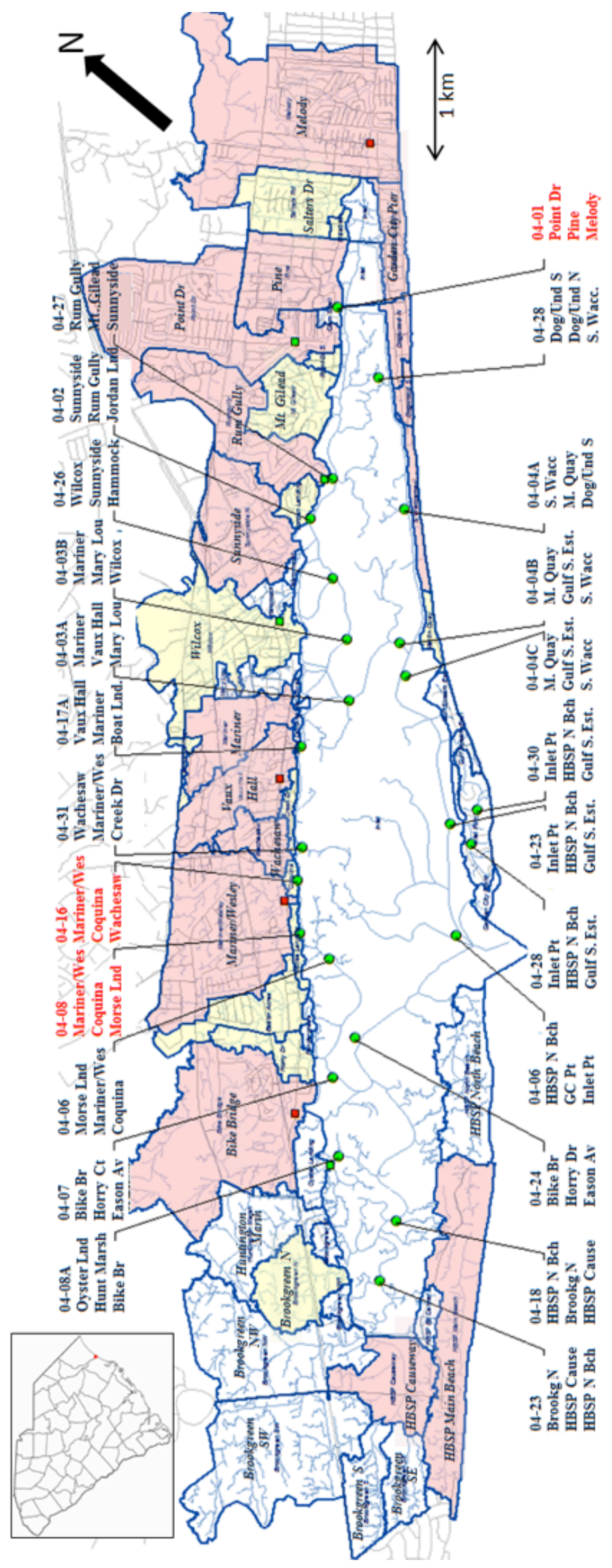

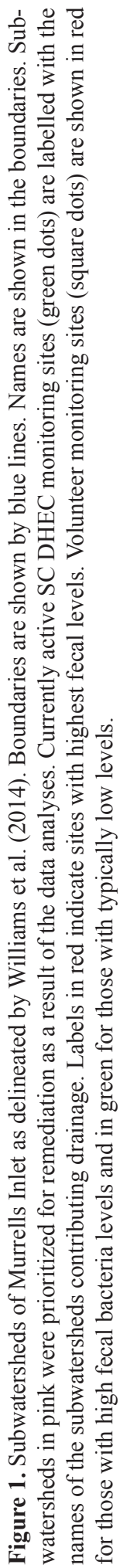


Table 2. Percent contraventions of SC DHEC's daily maximum E. coli water quality criteria as measured in the tributary waters of Murrells Inlet from July 2009 to May 2015 by the Murrells Inlet Volunteer Water Quality program.

\begin{tabular}{c|c|c}
\hline Sample Site & $\begin{array}{c}\text { Sample } \\
\text { Count }\end{array}$ & $\begin{array}{c}\% \\
\text { Contraventions }\end{array}$ \\
\hline Pond at Woodland Drive & 139 & 70 \\
\hline Canal at Point Drive & 139 & 3 \\
\hline Run Gully Creek & 139 & 3 \\
\hline Pond at Marina Colony & 139 & 16 \\
\hline Stream at HS & 139 & 78 \\
\hline Stream at BHR & 140 & 90 \\
\hline Stream at Bike Bridge & 139 & 40 \\
\hline Beach at Oyster Landing & 140 & 2 \\
\hline
\end{tabular}

Criteria are for recreational use of Class FW waters (349/100mL)

detected in the sediments of these small tributary streams, with concentrations being highly variable over space and time (Anderson and Greoski, 2010). Concurrent water measurements performed at upstream sites under wet and dry conditions generated similar results, suggesting episodic inputs from wildlife living in the stream corridors. This finding was also observed by other spatial surveys conducted over the years by SC DHEC, Georgetown County, and the volunteer monitors.

Watershed Plan Development. Concern voiced by the volunteers over their findings led the local community group, Murrells Inlet 2020, to lobby for development of a watershed plan (Young et al. 2014). In 2012, SC DHEC awarded the Waccamaw Council of Governments (COG) US EPA Section 319 funding to lead development of a watershedbased plan. The primary goal of the plan was to outline strategies for achieving fecal coliform load reductions. The COG developed this plan collaboratively with a steering committee comprised of stormwater managers from Horry and Georgetown counties, Murrells Inlet 2020, volunteer water quality monitors, Earthworks, Inc., scientists from Coastal Carolina and Clemson Universities, and concerned members of the community (Newquist 2014).

The plan was approved by SC DHEC in 2014. It includes a detailed list of prioritized fundable remediation projects designed to reduce fecal coliform loading to Murrells Inlet. These projects were developed from an understanding of fecal sources and transport pathways obtained from a comprehensive review of all existing data and prior microbial source tracking efforts.

\section{PROJECT OBJECTIVE/GOALS}

The primary objective of the data review was to assess all existing information to obtain a state of the knowledge understanding of fecal bacteria sources and transport pathways in the Murrells Inlet watershed. The watershed plan had to be developed in one year, so no new data could be collected. Thus an additional goal was to identify crucial data gaps and develop action items to include in the plan for obtaining these data.

Statistical analyses of existing fecal bacteria data from SC DHEC and the volunteer water quality monitoring program were designed to answer the following questions as posed by the steering committee that formulated the watershed plan:

1. Are some impaired locations more problematic than others, i.e. which sites have persistently elevated concentrations of fecal bacteria?

2. What are the ultimate source(s) and transport process(es) contributing to the bacterial water quality impairments?

3. Why are some sites attaining water quality criteria and others not?

4. Where and why has the acreage of shellfish closures been changing, i.e., have the fecal bacteria levels at any sites increased or decreased over time? If so, what has been causing these trends?

Ultimately these questions were used to prioritize subwatersheds for remediation efforts. Drivers of fecal bacteria trends that were evaluated to help answer these questions included: rain, i.e., transport via overland runoff due to stormwater flows, as well as tides, salinity, and changes in land use/land cover.

It was hypothesized that

1. Rainfall is a major transport agent of fecal bacteria, i.e., fecal bacteria concentrations would be higher in samples collected following rainfall as compared to antecedent dry periods and fecal bacteria concentrations would be higher in samples of lower salinity.

2. Sites with higher fecal bacteria levels are located immediately downstream of the most urbanized subwatersheds.

3. Shellfish beds not subject to closure are located furthest from land.

4. Fecal bacteria concentrations have increased in subwatersheds where urbanization has increased.

5. Tidal flushing reduces fecal bacteria numbers, i.e., fecal bacteria concentrations are higher in samples collected during low tide as compared to high tide, and fecal bacteria concentrations are higher in samples of lower salinity.

\section{METHODS}

Bacteria concentration data from SC DHEC's shellfish monitoring program (1967-2011) and a local volunteer water quality monitoring program (2008-2012) were used to elucidate spatial and temporal trends in bacteria levels and their causative drivers. Other ancillary data evaluated 
included rain, salinity, subwatershed boundaries, and land use-land cover. Details are provided below including inherent limitations in the fecal bacteria indicator data as they relate to sample site location and sampling frequency.

The steering committee that developed the watershed plan participated in selection of statistical tests, reasonable assumptions, and modes of data presentation including GIS mapping. This committee also reviewed the results and collaboratively crafted summary conclusions that were incorporated into the watershed-based plan. A technical advisory committee provided peer review of the data analyses.

Data Sources. Watershed mapping was performed by Earthworks, Inc. This included delineation of 51 subwatersheds and mapping of flow paths, soils, and impervious surface. These were used to generate maps of curve numbers (Williams et al. 2014). Using these maps, Georgetown County performed peak flow determinations for 2-year design rain events using the TR-55 model that is designed for small urbanizing watersheds. Comparison of land-use land cover maps for 1994 and 2012 was used to identify subwatersheds that had undergone recent significant urbanization (Williams et al. 2014).

Statistical tests were performed on fecal coliform data from SC DHEC's National Shellfish Sanitation Program collected from 1967 to 2011. This was the entire period of record that SC DHEC could provide within the project time frame. Data collected after 2011 were used in some analyses as they became available.

Mike Pearson (SC DHEC) provided shellfish program data from 1990 to present, including salinity and tidal stage. To interpret the tidal stage information, SC DHEC provided their field sheet coding information. Legacy data were obtained by download from STORET. The earliest data obtained are from 1967. Significant data gaps are present for periods that Mike Pearson suggests should have data. For some years, no data are present for any of the sites. Another limitation to the data collected prior to the early 1990's includes a change in analytical methodology. This involved a delay in adoption of a modernized version of the look-up tables provided in Standard Methods used to transform tube counts into MPN/100 mL. Some of the legacy data suggest that special studies were done such that multiple samples were collected per month and in some cases, per day.

Statistical tests were also performed on E. coli and total coliform data collected at eight sites by the Murrells Inlet volunteer water quality monitoring program from 2008 to 2012. Ancillary data used from this monitoring program included conductivity. Most of these sampling sites are located in freshwater tributary streams that discharge into saline tidal creeks, so salinities are generally below 5 . This is also why the freshwater fecal indicator bacteria, E. coli, is measured by this program. The National Shellfish Sanitation Program requires the use of fecal coliforms as the fecal indicator bacteria.

Daily rain accumulations from the nearest National Climate Data Center (NCDC) monitoring station was used to obtain a rain record back into the 1960 's. This sampling site (COOP:381093) is located 1.5 miles inland in Brookgreen Gardens, Murrells Inlet, SC. We acknowledge that the highly localized nature of rainfall along the southeastern coast, especially during the summer, limits the usability of this source. The binning of data on a daily basis also creates limitations in interpreting the fecal coliform data.

Data Analyses. All hypothesis testing relied on nonparametric approaches since the fecal bacteria data are not normally distributed. Nonparametric tests are less powerful than the analogous parametric tests, making it more difficult to detect significant trends or differences. This leads to a conservative reporting of significant differences or trends. In other words, absence of significance does not mean the differences or trends were not present; they just couldn't be detected by the nonparametric test.

All statistical analyses and graphing were performed with Microsoft's Excel 2007 and Systat's SigmaPlot V12.3. Mann-Kendall tests for time series trends were performed with code downloaded from Helsel et al. (2006).

Results were presented as time trend graphs, box plots, bar graphs, scatter plots, and matrices. All the statistical test results were collated by site into a summary matrix to provide a weight-of-evidence approach to support overarching spatial and temporal trends. In this summary matrix, sites were grouped by subwatersheds and information on peak runoff and land use/land cover were included to provide insight into terrestrial drivers of spatial trends. This visualization also helped identify subwatersheds to prioritize for remediation.

Spatial and temporal trends in the SC DHEC data were visualized in several ways:

1. Graphically by plotting geometric means (geomeans) and Est. $90^{\text {th }}$ percentiles for each monitoring site as reported in the SC DHEC shellfish reports.

2. As a color-coded matrix to show water quality criteria contraventions by site and year.

3. Annual box plots for each site with a LOWESS curve fit (locally weighted scatterplot smoothing).

4. GIS mapping of concentrations binned by quartiles for two decades: 2000 to 2009 and 2009 to present. The volunteer monitoring data are included in these maps.

Wet vs Dry Tests for Difference. To test the hypothesis that fecal coliform levels are higher under wet as compared to dry conditions, the Mann-Whitney U test was used to compare wet and dry data. Definitions of wet and dry conditions were optimized from a sensitivity analysis.

This resulted in the following bins: wet data were ones collected within 3 days of a daily rain accumulation of at least 0.5 " $(12.7 \mathrm{~mm})^{3}$, and dry data were ones collected after at least 3 days of 0.0 " $(0.0 \mathrm{~mm})$ daily rain accumulation. The most recent complete decade was selected for study, i.e., 2000 to 2009 , to produce a dataset of large enough size to

\footnotetext{
${ }^{3}$ This is also a standard rain event used in NPDES permits and regulations.
} 
enable detection of significant differences and to best reflect current conditions. The results were presented visually on the boxplotted data and rated as either: (1) highly significant $(p<0.05)$, (2) significant $(0.05<p<0.10)$, or ( 3$)$ no significant difference $(p>0.10)$. The latter means that the test failed to find sufficient evidence of difference.

Several approaches were used to test the hypothesis that fecal coliform levels have increased over time. This hypothesis was formulated in recognition of: (1) a historical increase in the number of TMDL sites from 8 in 2005 to 20 in 2012 and (2) increasing trends in the time trend plots of the geomeans and Est. 90 $0^{\text {th }}$ percentiles (Figures 2 and 3) especially at the ends of the record, generally starting with the 2007 shellfish report. An independent verification that the trend analyses were done appropriately is provided by the finding of decreasing trend at sites that are no longer being sampled, i.e., SC DHEC Sites 04-01a, 04-03, 04-04, 04-05, 04-17, and 04-22, and increasing trend at sites that had been added to the TMDL due to their non-supporting status, i.e., Sites 04-04a, 04-17a, 04-28 and 04-31.

Tests for Time Trends. The Mann-Kendall test (Hirsch and Slack 1984) was used to test for the presence of a monotonic increasing or decreasing trend over time. At least five years of data are required. The test is robust against data gaps (Meals et al. 2011), is non parametric, and has been widely used for evaluating trends in fecal bacteria data. It is also robust against changes in units, which accommodates SC DHEC's upper reporting limit of $1600 \mathrm{MPN} / 100 \mathrm{~mL}$ for fecal coliforms.

The Mann-Kendall test for trend was run for each site using all the data available. In some cases, data prior to the method change in 1990 were available and used. The earliest data dated from 1967. Site 04-01 is notable for having data back to 1967 and makes a good test case as it is also the most contaminated of the sites in Murrells Inlet. Values for the slope of the linear trend and $p$ value were used to characterize the strength of the relationship between fecal coliform concentrations and time. Results were considered highly significant if $\mathrm{p}<0.05$ and significant if $0.05<\mathrm{p}<0.10$.

Although this test can be used to control for effects of seasonality, there was no process-based reason to hypothesize seasonality in Murrells Inlet and data exploration did not reveal evidence of such trends. The Mann-Kendall trend test also has an option to control for the effect of rainfall. Since the MannWhitney $U$ test results suggested a significant influence of rain at most sites, the Mann-Kendall test was also performed to check for trend when the influence of rain was removed.

The Mann-Kendall test was rerun using only the last five years of data (2007-2012) to verify the visual observation of recent increasing trends in the geomeans and Est. $90^{\text {th }}$ percentile time trend plots (Figures 2 and 3 ).

For the volunteer monitoring data, less than five years of data were available, so the presence of a trend was evaluated by performing a linear regression on the log transformed E. coli data.

Effect of Tidal Stage. To test the hypothesis that fecal coliform levels are higher during low tide as compared to high tide, the Mann-Whitney U test was used to compare data binned into two categories of tidal stage. Low tide was defined as stages from $3 / 4$ ebb to $1 / 4$ flood and high tide from $3 / 4$ flood to $1 / 4 \mathrm{ebb}$. Differences were considered highly significant for $\mathrm{p}<0.05$ and somewhat significant for $0.05<\mathrm{p}<0.10$. This was tested at each site with SC DHEC fecal coliform data collected from 1990 to 2011.

Effect of Salinity. To test the hypothesis that fecal coliform levels are higher when salinity is lower, a linear regression was used on data from all sites. To ensure sufficient low salinity data to detect a trend, the regression was performed on data from all sites combined from 1990 to 2011.

Subwatershed Prioritization. All the statistical test results were collated by sampling site into a summary matrix (Table 10) to provide a weight-of-evidence approach to understanding the causes of overarching spatial and temporal trends. Sites were grouped by subwatershed. Information on peak runoff and drainage acreage was included to provide insight into terrestrial drivers of spatial trends. The matrix was aligned against a map of sampling sites to help visualize spatial trends. Color coding was used to highlight large subwatersheds with high storm flows as inferred from TR-55 2-year event calculations. A similar color-coding scale was used to identify statistical results that indicated persistent, high and increasing levels of fecal bacteria from the SC DHEC and volunteer monitoring data. This enabled identification of subwatersheds with persistent and high levels of fecal bacteria contamination as compared to ones with low levels and subwatersheds with increasing levels as compared to others with declining or stable levels.

\section{RESULTS}

Graphical visualization. The geomeans and Est. $90^{\text {th }}$ percentiles published in the SC DHEC shellfish reports for each site from 1992 to 2011 are plotted as time series graphs in Figures 2 and 3. Each data point represents three years of data, using the middle year for the $\mathrm{x}$ axis label, so there is overlap in the data analogous to a moving average. The water quality criteria are represented by the red line. These plots are grouped into three tiers based on concentration range. The highest concentrations were put into Tier 1 . The Est. $90^{\text {th }}$ percentile is a tighter criterion than the geomean threshold, so the former is more frequently contravened than the latter. Nonetheless, the tier groupings are consistent between the two water quality criteria, which provides for an identification of sites that have been most consistently and highly contaminated (04-01, 04-16, and 04-8). Sampling at Site 04-01A ended in 2001.

Tables 3 and 4 are color-coded matrices that show water quality criteria contraventions by site and year for the geomeans and Est. $90^{\text {th }}$ percentiles, respectively. The site results were split into quartiles to identify sites with the highest frequency of contraventions (Table 5). These rankings were 
used to generate the index labeled "Hot" in the summary matrix in Table 10. These sites are identical to the ones identified in Figures 2 and 3 and demonstrate that the sites with the highest levels of fecal coliform have also had been consistently contaminated. The results were also used to identify years with the highest frequency of contraventions (Table 6). The last two shellfish reports had unusually high levels of contraventions suggesting an increase in contamination over this period.

Annual box plots with LOWESS curve fit (locally weighted scatterplot smoothing) were used to illustrate the results of the trend analyses performed with the Mann Kendall test. An example is provided in Figure 4 for Site 04-01, which had a pronounced trend of increasing fecal coliforms as determined by the Mann-Kendall test and visualized by the LOWESS curve fit. The annual boxplots demonstrate that data variance has been uniform over time, enabling use of the Mann-Kendall test for monotonic trend.

Figure 5 shows GIS mapping of the Est. $90^{\text {th }}$ percentiles binned by quartiles for two decades: 1999 to 2009 and 2009 to present. The volunteer monitoring data are included in these maps as their $90^{\text {th }}$ percentiles. These maps illustrate that the most contaminated sites are located nearest the mainland where urbanization is highest (middle to north end of the Inlet) and that the volunteer monitoring sites with the most persistently high $E$. coli levels are located upstream of the SC DHEC sites that have the most persistently high fecal coliform levels.

Wet vs Dry Tests for Difference. Table 7 lists the results of the Mann-Whitney U tests used to determine significant differences between wet and dry weather data by site. The results include the sensitivity analysis that evaluated the appropriate time window to use for antecedent dry and wet conditions. The 3-day window did best at detecting significant differences, providing some insight into the time to concentration within the subwatersheds. Of the sites monitored during this period, 17 of 28 (61\%) had some evidence of higher fecal coliform concentrations under wet as compared to dry conditions. A similar test for difference was performed on the volunteer monitoring E. coli data. Half of the sites had evidence of wet samples having higher fecal bacteria concentrations than during dry weather using the 3-day window.

Tests for time trends. Table 8 lists the results from the Mann Kendall and linear regression tests used to test for a significant increase in fecal bacteria concentrations over time. If slopes were 0.00 , a trend was not considered to be present even if the $\mathrm{p}$ value was highly significant.

Tests performed on the entire dataset are designated as being "with rain" or "wet". The Mann Kendall results obtained by controlling for the influence of rain (data collected within 3 days of a 0.5 " daily rain accumulation) are labelled "dry"; this version of the test looks for trend in the absence of the controlled driver, i.e. rain. For the entire dataset, two sites (04-01 and 0404b) had evidence for increasing fecal coliform levels under wet and dry conditions. Four sites had evidence for increasing trend under dry conditions only (04-02, 04-06, 04-26 and 0431). Three sites had evidence of decreasing trend under dry and wet conditions (04-17 and 04-01a (both no longer sampled) and 04-29). Two sites had evidence for increasing trend under dry conditions only (04-23 and 04-24). These tests were rerun for data from 2007-2012 since Figures 2 and 3 suggested a recent increase in fecal coliform levels. Significant increasing trends under wet and dry conditions were detected at six sites (0401, 04-04a, 04-04b, 04-04c, 04-06, and 04-30) and under wet conditions only at two sites (04-02 and 04-27).

Site 04-01 had the largest slopes by far of all the sites, with the most recent increasing trend being on the order of $10 \mathrm{MPN} / 100 \mathrm{~mL}$ per year. This begged the question as to whether Site 04-01, the most contaminated of the sites, was ever attaining the Class SFH water quality criteria, i.e. could natural sources always have been present and flushing so limited that this site was always "contaminated"? To answer this question, legacy data were analyzed by binning geomeans and Est. $90^{\text {th }}$ percentiles in 3-year running groups similar to Figures 2 and 3. The resulting time trend plots suggest that by the mid 1970's, the geomean and Est. $90^{\text {th }}$ percentile criteria were no longer being met. But due to missing data, these conclusions are not robust. To address this, the data were binned into larger and non-overlapping time steps to generate sample sets of similar size. Time trends were explored for percent exceedances in two other water quality criteria used in the NSSP, i.e., 88 and $260 \mathrm{MPN} / 100 \mathrm{~mL}$. These time trends indicate that the fecal coliform levels were contravening the 88 and $260 \mathrm{MPN} / 100 \mathrm{~mL}$ criteria in less than $10 \%$ of the samples until the mid-1970's. This provides additional evidence that water quality was meeting NSSP criteria even at the presently most contaminated site (04-01) prior to the 1980's.

For the volunteer monitoring data, less than five years of data were available, so the presence of a trend was evaluated by performing a linear regression on log transformed $E$. coli data. The only trends detected were declining ones at BHR and HS.

Effect of tidal stage. Before binning data into high and low tide cohorts, the data were evaluated to verify that sampling had been conducted equally at all 8 stages of the tide distinguished by SC DHEC as part of their shellfish program monitoring protocol. The Mann-Whitney $U$ test was used to detect differences in fecal coliform levels between low and high tide. The results are shown in Table 9. Twenty-six of the 30 sites had evidence for significantly higher fecal coliform on low tide as compared to high tide. Of the other four sites, one is relatively clean (04-04C) having only one sample $>50$ MPN/100 mL, one is near the SC Department of Natural Resources' boat ramp where resuspension from heavy boat use is likely occurring at all tidal stages, and the other two sites are located in Oyster Cove (04-29 and 04-30) where flushing is likely highly restricted.

Sites that had much higher frequencies of relatively high fecal coliform concentrations (aka $>50 \mathrm{MPN} / 100 \mathrm{~mL}$ ) during low tide as compared to high tide are interpreted as having the largest difference in water flows between low and high tide. These are sites 04-01A (no longer sampled), 04-07, 0408A, 04-18, and 04-28. These sites are likely to benefit most from dredging as a strategy for reducing fecal coliform levels. 


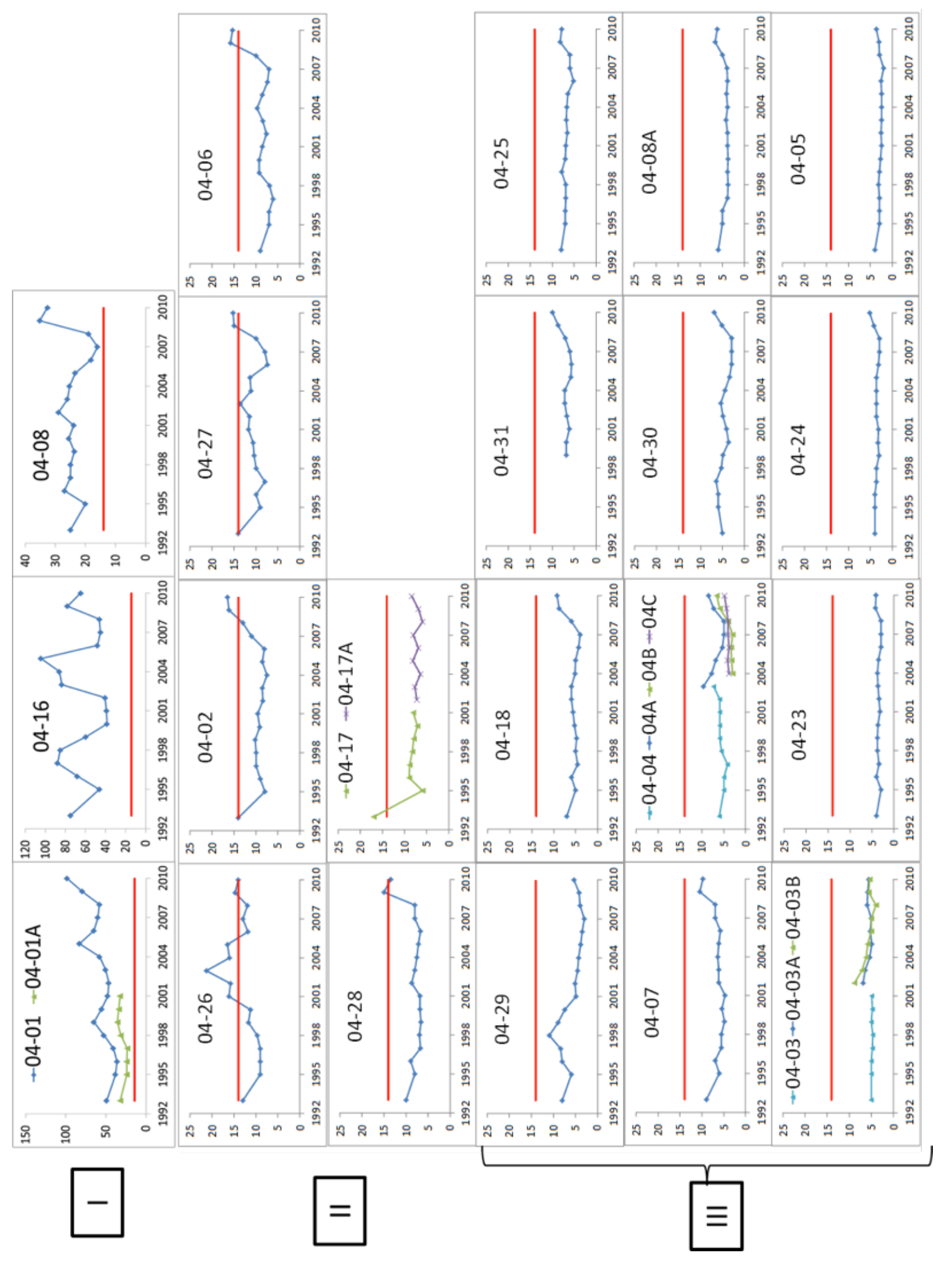

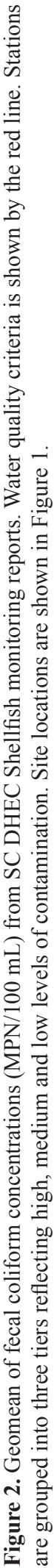




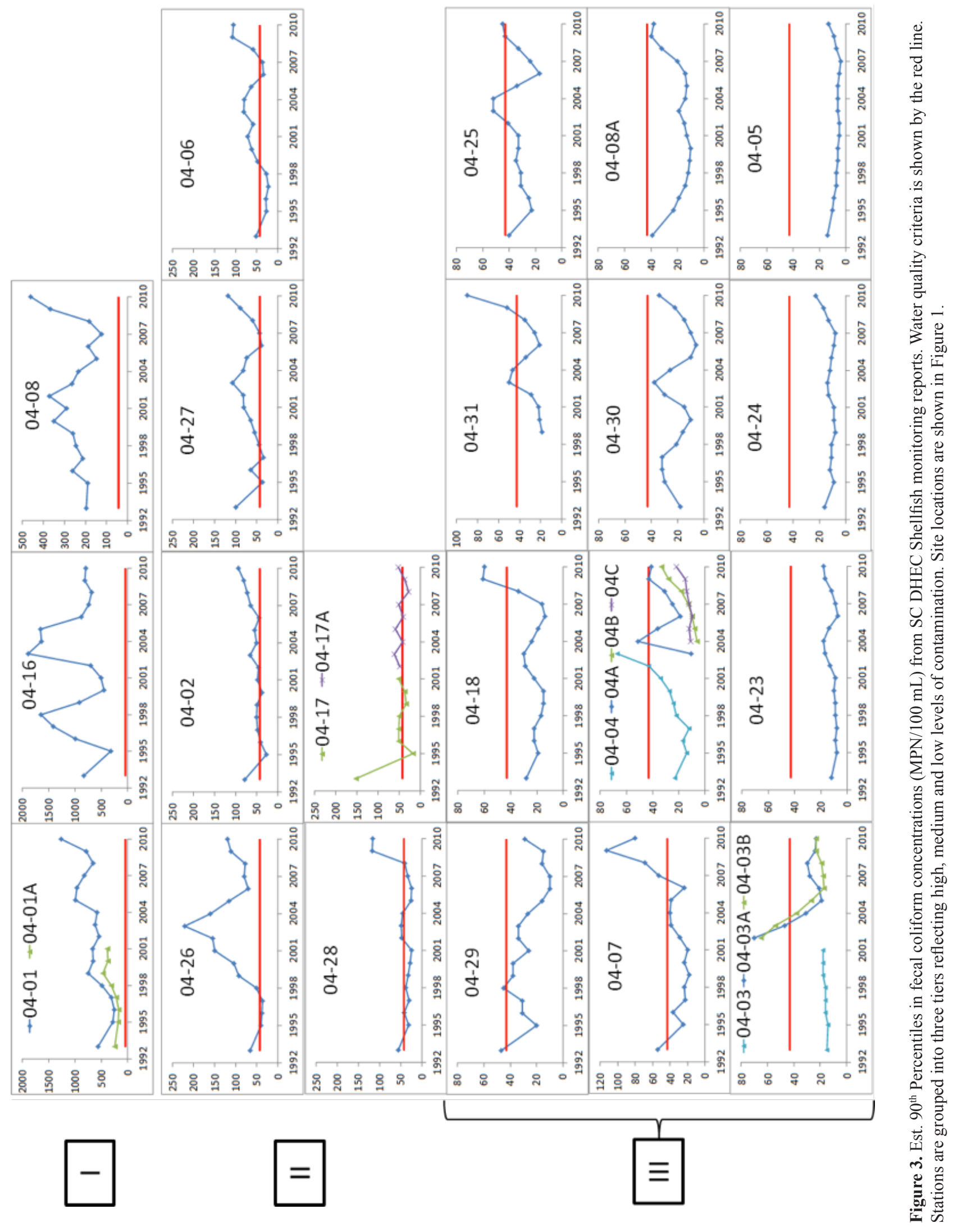


Table 3. Contraventions of geomean water quality criteria as reported in the annual Shellfish Monitoring Reports. U $=$ under the water quality criteria. $\mathrm{O}=$ over the water quality criteria.

\begin{tabular}{|c|c|c|c|c|c|c|c|c|c|c|c|c|c|c|c|c|c|c|}
\hline \multirow[b]{2}{*}{ Site } & \multicolumn{17}{|c|}{ Shellfish Reports } & \multirow[b]{2}{*}{$\%$ Over } \\
\hline & 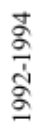 & 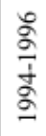 & $\frac{\hat{\sigma}}{\text { ڤे }}$ & $\frac{\infty}{\frac{\infty}{\delta}}$ & $\frac{\frac{\partial}{\sigma}}{\frac{1}{2}}$ & 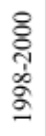 & 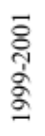 & 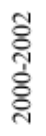 & 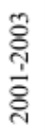 & 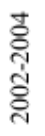 & 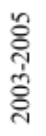 & 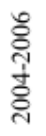 & 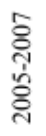 & 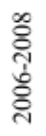 & 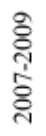 & 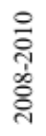 & 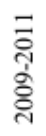 & \\
\hline 1 & $\mathrm{O}$ & $\mathrm{O}$ & $\mathrm{O}$ & $\mathrm{O}$ & $\mathrm{O}$ & $\mathrm{O}$ & $\mathrm{O}$ & $\mathrm{O}$ & $\mathrm{O}$ & $\mathrm{O}$ & $\mathrm{O}$ & $\mathrm{O}$ & $\mathrm{O}$ & $\mathrm{O}$ & $\mathrm{O}$ & $\mathrm{O}$ & $\mathrm{O}$ & $100 \%$ \\
\hline $1 \mathrm{~A}$ & $\mathrm{O}$ & $\mathrm{O}$ & $\mathrm{O}$ & $\mathrm{O}$ & $\mathrm{O}$ & $\mathrm{O}$ & $\mathrm{O}$ & $\mathrm{O}$ & \multicolumn{9}{|c|}{ Monitoring discontinued beyond this date } & $100 \%$ \\
\hline 2 & $\mathrm{U}$ & $\mathrm{U}$ & $\mathrm{U}$ & $\mathrm{U}$ & $\mathrm{U}$ & $\mathrm{U}$ & $\mathrm{U}$ & $\mathrm{U}$ & $\mathrm{U}$ & $\mathrm{U}$ & U & $\mathrm{U}$ & $\mathrm{U}$ & $\mathrm{U}$ & $\mathrm{U}$ & $\mathrm{O}$ & $\mathrm{O}$ & $12 \%$ \\
\hline 3 & $\mathrm{U}$ & $\mathrm{U}$ & $\mathrm{U}$ & $\mathrm{U}$ & $\mathrm{U}$ & $\mathrm{U}$ & $\mathrm{U}$ & $\mathrm{U}$ & \multicolumn{9}{|c|}{ Monitoring discontinued beyond this date } & $0 \%$ \\
\hline $03 \mathrm{~A}$ & \multirow{2}{*}{\multicolumn{8}{|c|}{$\begin{array}{l}\text { Monitoring not initiated until this date } \\
\text { Monitoring not initiated until this date }\end{array}$}} & $\mathrm{U}$ & $\mathrm{U}$ & $\mathrm{U}$ & $\mathrm{U}$ & $\mathrm{U}$ & $\mathrm{U}$ & $\mathrm{U}$ & $\mathrm{U}$ & $\mathrm{U}$ & $0 \%$ \\
\hline 03B & & & & & & & & & $\mathrm{U}$ & $\mathrm{U}$ & $\mathrm{U}$ & $\mathrm{U}$ & $\mathrm{U}$ & $\mathrm{U}$ & $\mathrm{U}$ & $\mathrm{U}$ & $\mathrm{U}$ & $0 \%$ \\
\hline 4 & $\mathrm{U}$ & $\mathrm{U}$ & $\mathrm{U}$ & $\mathrm{U}$ & $\mathrm{U}$ & $\mathrm{U}$ & $\mathrm{U}$ & $\mathrm{U}$ & $\mathrm{U}$ & $\mathrm{U}$ & Mot & itorit & g dis & conti & lued & & & $0 \%$ \\
\hline $04 \mathrm{~A}$ & \multicolumn{10}{|c|}{ Monitoring not initiated until this date } & $\mathrm{U}$ & $\mathrm{U}$ & $\mathrm{U}$ & $\mathrm{U}$ & $\mathrm{U}$ & $\mathrm{U}$ & $\mathrm{U}$ & $0 \%$ \\
\hline 04B & \multirow{2}{*}{\multicolumn{10}{|c|}{$\begin{array}{l}\text { Monitoring not initiated until this date } \\
\text { Monitoring not initiated until this date }\end{array}$}} & $\mathrm{U}$ & $\mathrm{U}$ & $\mathrm{U}$ & $\mathrm{U}$ & $\mathrm{U}$ & $\mathrm{U}$ & $\mathrm{U}$ & $0 \%$ \\
\hline $04 \mathrm{C}$ & & & & & & & & & & & $\mathrm{U}$ & $\mathrm{U}$ & $\mathrm{U}$ & $\mathrm{U}$ & $\mathrm{U}$ & $\mathrm{U}$ & $\mathrm{U}$ & $0 \%$ \\
\hline 5 & $\mathrm{U}$ & $\mathrm{U}$ & $\mathrm{U}$ & $\mathrm{U}$ & $\mathrm{U}$ & $\mathrm{U}$ & $\mathrm{U}$ & $\mathrm{U}$ & $\mathrm{U}$ & $\mathrm{U}$ & $\mathrm{U}$ & $\mathrm{U}$ & $\mathrm{U}$ & $\mathrm{U}$ & $\mathrm{U}$ & $\mathrm{U}$ & $\mathrm{U}$ & $0 \%$ \\
\hline 6 & $\mathrm{U}$ & $\mathrm{U}$ & $\mathrm{U}$ & $\mathrm{U}$ & $\mathrm{U}$ & $\mathrm{U}$ & $\mathrm{U}$ & $\mathrm{U}$ & $\mathrm{U}$ & $\mathrm{U}$ & $\mathrm{U}$ & $\mathrm{U}$ & $\mathrm{U}$ & $\mathrm{U}$ & $\mathrm{U}$ & $\mathrm{O}$ & $\mathrm{O}$ & $12 \%$ \\
\hline 7 & $\mathrm{U}$ & $\mathrm{U}$ & $\mathrm{U}$ & $\mathrm{U}$ & $\mathrm{U}$ & $\mathrm{U}$ & $\mathrm{U}$ & $\mathrm{U}$ & $\mathrm{U}$ & $\mathrm{U}$ & $\mathrm{U}$ & $\mathrm{U}$ & $\mathrm{U}$ & $\mathrm{U}$ & $\mathrm{U}$ & $\mathrm{U}$ & $\mathrm{U}$ & $0 \%$ \\
\hline 8 & $\mathrm{O}$ & $\mathrm{O}$ & $\mathrm{O}$ & $\mathrm{O}$ & $\mathrm{O}$ & $\mathrm{O}$ & $\mathrm{O}$ & $\mathrm{O}$ & $\mathrm{O}$ & $\mathrm{O}$ & $\mathrm{O}$ & $\mathrm{O}$ & $\mathrm{O}$ & $\mathrm{O}$ & $\mathrm{O}$ & $\mathrm{O}$ & $\mathrm{O}$ & $100 \%$ \\
\hline $08 \mathrm{~A}$ & $\mathrm{U}$ & $\mathrm{U}$ & $\mathrm{U}$ & $\mathrm{U}$ & $\mathrm{U}$ & $\mathrm{U}$ & $\mathrm{U}$ & $\mathrm{U}$ & $\mathrm{U}$ & $\mathrm{U}$ & $\mathrm{U}$ & $\mathrm{U}$ & $\mathrm{U}$ & $\mathrm{U}$ & $\mathrm{U}$ & $\mathrm{U}$ & $\mathrm{U}$ & $0 \%$ \\
\hline 16 & $\mathrm{O}$ & $\mathrm{O}$ & $\mathrm{O}$ & $\mathrm{O}$ & $\mathrm{O}$ & $\mathrm{O}$ & $\mathrm{O}$ & $\mathrm{O}$ & $\mathrm{O}$ & $\mathrm{O}$ & $\mathrm{O}$ & $\mathrm{O}$ & $\mathrm{O}$ & $\mathrm{O}$ & $\mathrm{O}$ & $\mathrm{O}$ & $\mathrm{O}$ & $100 \%$ \\
\hline 17 & $\mathrm{O}$ & $\mathrm{U}$ & U & $\mathrm{U}$ & $\mathrm{U}$ & $\mathrm{U}$ & $\mathrm{U}$ & $\mathrm{U}$ & \multicolumn{9}{|c|}{ Monitoring discontinued beyond this date } & $13 \%$ \\
\hline $17 \mathrm{~A}$ & \multicolumn{8}{|c|}{ Monitoring not initiated until this date } & $\mathrm{U}$ & $\mathrm{U}$ & U & $\mathrm{U}$ & $\mathrm{U}$ & $\mathrm{U}$ & $\mathrm{U}$ & $\mathrm{U}$ & $\mathrm{U}$ & $0 \%$ \\
\hline 18 & $\mathrm{U}$ & $\mathrm{U}$ & $\mathrm{U}$ & $\mathrm{U}$ & $\mathrm{U}$ & $\mathrm{U}$ & $\mathrm{U}$ & $\mathrm{U}$ & $\mathrm{U}$ & $\mathrm{U}$ & $\mathrm{U}$ & $\mathrm{U}$ & $\mathrm{U}$ & $\mathrm{U}$ & $\mathrm{U}$ & $\mathrm{U}$ & $\mathrm{U}$ & $0 \%$ \\
\hline 22 & $\mathrm{U}$ & \multicolumn{16}{|c|}{ Monitoring discontinued beyond this date } & $0 \%$ \\
\hline 23 & $\mathrm{U}$ & $\mathrm{U}$ & $\mathrm{U}$ & $\mathrm{U}$ & $\mathrm{U}$ & $\mathrm{U}$ & $\mathrm{U}$ & $\mathrm{U}$ & $\mathrm{U}$ & $\mathrm{U}$ & $\mathrm{U}$ & $\mathrm{U}$ & $\mathrm{U}$ & $\mathrm{U}$ & $\mathrm{U}$ & $\mathrm{U}$ & $\mathrm{U}$ & $0 \%$ \\
\hline 24 & $\mathrm{U}$ & $\mathrm{U}$ & $\mathrm{U}$ & $\mathrm{U}$ & $\mathrm{U}$ & $\mathrm{U}$ & $\mathrm{U}$ & $\mathrm{U}$ & $\mathrm{U}$ & $\mathrm{U}$ & $\mathrm{U}$ & $\mathrm{U}$ & $\mathrm{U}$ & $\mathrm{U}$ & $\mathrm{U}$ & $\mathrm{U}$ & $\mathrm{U}$ & $0 \%$ \\
\hline 25 & $\mathrm{U}$ & $\mathrm{U}$ & $\mathrm{U}$ & $\mathrm{U}$ & $\mathrm{U}$ & $\mathrm{U}$ & $\mathrm{U}$ & $\mathrm{U}$ & $\mathrm{U}$ & $\mathrm{U}$ & $\mathrm{U}$ & $\mathrm{U}$ & $\mathrm{U}$ & $\mathrm{U}$ & $\mathrm{U}$ & $\mathrm{U}$ & $\mathrm{U}$ & $0 \%$ \\
\hline 26 & $\mathrm{U}$ & $\mathrm{U}$ & $\mathrm{U}$ & $\mathrm{U}$ & $\mathrm{U}$ & $\mathrm{U}$ & $\mathrm{U}$ & $\mathrm{O}$ & $\mathrm{O}$ & $\mathrm{O}$ & $\mathrm{O}$ & $\mathrm{O}$ & $\mathrm{U}$ & $\mathrm{U}$ & $\mathrm{U}$ & $\mathrm{O}$ & $\mathrm{O}$ & $41 \%$ \\
\hline 27 & $\mathrm{U}$ & $\mathrm{U}$ & $\mathrm{U}$ & $\mathrm{U}$ & $\mathrm{U}$ & $\mathrm{U}$ & $\mathrm{U}$ & $\mathrm{U}$ & $\mathrm{U}$ & $\mathrm{U}$ & $\mathrm{U}$ & $\mathrm{U}$ & $\mathrm{U}$ & $\mathrm{U}$ & $\mathrm{U}$ & $\mathrm{O}$ & $\mathrm{O}$ & $12 \%$ \\
\hline 28 & $\mathrm{U}$ & $\mathrm{U}$ & $\mathrm{U}$ & $\mathrm{U}$ & $\mathrm{U}$ & $\mathrm{U}$ & $\mathrm{U}$ & $\mathrm{U}$ & $\mathrm{U}$ & $\mathrm{U}$ & $\mathrm{U}$ & $\mathrm{U}$ & $\mathrm{U}$ & $\mathrm{U}$ & $\mathrm{U}$ & $\mathrm{O}$ & $\mathrm{U}$ & $6 \%$ \\
\hline 29 & $\mathrm{U}$ & $\mathrm{U}$ & $\mathrm{U}$ & $\mathrm{U}$ & $\mathrm{U}$ & $\mathrm{U}$ & $\mathrm{U}$ & $\mathrm{U}$ & $\mathrm{U}$ & $\mathrm{U}$ & $\mathrm{U}$ & $\mathrm{U}$ & $\mathrm{U}$ & $\mathrm{U}$ & $\mathrm{U}$ & $\mathrm{U}$ & $\mathrm{U}$ & $0 \%$ \\
\hline 30 & $\mathrm{U}$ & $\mathrm{U}$ & $\mathrm{U}$ & $\mathrm{U}$ & $\mathrm{U}$ & $\mathrm{U}$ & $\mathrm{U}$ & $\mathrm{U}$ & $\mathrm{U}$ & $\mathrm{U}$ & $\mathrm{U}$ & $\mathrm{U}$ & $\mathrm{U}$ & $\mathrm{U}$ & $\mathrm{U}$ & $\mathrm{U}$ & $\mathrm{U}$ & $0 \%$ \\
\hline 31 & \multicolumn{5}{|c|}{ Monitoring not initiated } & $\mathrm{U}$ & $\mathrm{U}$ & $\mathrm{U}$ & $\mathrm{U}$ & $\mathrm{U}$ & $\mathrm{U}$ & $\mathrm{U}$ & $\mathrm{U}$ & $\mathrm{U}$ & $\mathrm{U}$ & $\mathrm{U}$ & $\mathrm{U}$ & $0 \%$ \\
\hline 32 & \multicolumn{17}{|c|}{\begin{tabular}{|l|l} 
Monitoring not initiated until this date & $\mathrm{U}$
\end{tabular}} & $0 \%$ \\
\hline
\end{tabular}

Table 4. Contraventions of Est. $90^{\text {th }}$ percentile water quality criteria as reported in the annual Shellfish Monitoring Reports. $U=$ under the water quality criteria. $\mathrm{O}=$ over the water quality criteria.

\begin{tabular}{|c|c|c|c|c|c|c|c|c|c|c|c|c|c|c|c|c|c|c|}
\hline \multirow[b]{2}{*}{ Site } & \multicolumn{17}{|c|}{ Shellfish reports } & \multirow[b]{2}{*}{ ర్ } \\
\hline & 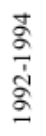 & $\begin{array}{l}\stackrel{\circ}{\circ} \\
\frac{1}{\dot{5}} \\
\stackrel{5}{\circ}\end{array}$ & $\frac{\hat{\sigma}}{\hat{\sigma}}$ & $\frac{\infty}{\circ} \frac{\circ}{\circ}$ & 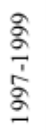 & 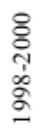 & 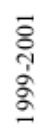 & 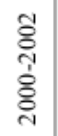 & 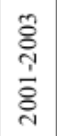 & 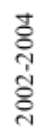 & 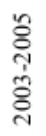 & 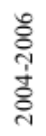 & 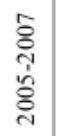 & 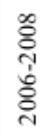 & 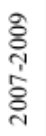 & 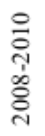 & $\begin{array}{l}\overrightarrow{\text { }} \\
\text { ळे } \\
\text { ઠे }\end{array}$ & \\
\hline 1 & $\mathrm{O}$ & $\mathrm{O}$ & $\mathrm{O}$ & $\mathrm{O}$ & $\mathrm{O}$ & $\mathrm{O}$ & $\mathrm{O}$ & $\mathrm{O}$ & $\mathrm{O}$ & $\mathrm{O}$ & $\mathrm{O}$ & $\mathrm{O}$ & $\mathrm{O}$ & $\mathrm{O}$ & $\mathrm{O}$ & $\mathrm{O}$ & $\mathrm{O}$ & $100 \%$ \\
\hline $1 \mathrm{~A}$ & $\mathrm{O}$ & $\mathrm{O}$ & $\mathrm{O}$ & $\mathrm{O}$ & $\mathrm{O}$ & $\mathrm{O}$ & $\mathrm{O}$ & $\mathrm{O}$ & \multicolumn{9}{|c|}{ Monitoring discontinued beyond this date } & $100 \%$ \\
\hline 2 & $\mathrm{O}$ & $\mathrm{U}$ & $\mathrm{U}$ & $\mathrm{O}$ & $\mathrm{O}$ & 0 & $\mathrm{U}$ & $\mathrm{O}$ & $\mathrm{O}$ & $\mathrm{O}$ & 0 & $\mathrm{O}$ & 0 & O & o & $\mathrm{O}$ & $\mathrm{O}$ & $82 \%$ \\
\hline 3 & $\mathrm{U}$ & $\mathrm{U}$ & $\mathrm{U}$ & $\mathrm{U}$ & $\mathrm{U}$ & $\mathrm{U}$ & $\mathrm{U}$ & $\mathrm{U}$ & \multicolumn{9}{|c|}{ Monitoring discontinued beyond this date } & $0 \%$ \\
\hline $03 \mathrm{~A}$ & \multirow{2}{*}{\multicolumn{8}{|c|}{$\begin{array}{l}\text { Monitoring not initiated until this date } \\
\text { Monitoring not initiated until this date }\end{array}$}} & $\mathrm{O}$ & $\mathrm{O}$ & $\mathrm{U}$ & $\mathrm{U}$ & $\mathrm{U}$ & $\mathrm{U}$ & $\mathrm{U}$ & $\mathrm{U}$ & $\mathrm{U}$ & $22 \%$ \\
\hline 03B & & & & & & & & & $\mathrm{O}$ & $\mathrm{O}$ & $\mathrm{U}$ & $\mathrm{U}$ & $\mathrm{U}$ & $\mathrm{U}$ & $\mathrm{U}$ & $\mathrm{U}$ & $\mathrm{U}$ & $22 \%$ \\
\hline 4 & $\mathrm{U}$ & $\mathrm{U}$ & $\mathrm{U}$ & $\mathrm{U}$ & $\mathrm{U}$ & $\mathrm{U}$ & $\mathrm{U}$ & $\mathrm{U}$ & $\mathrm{U}$ & $\mathrm{O}$ & Mon & torin & g disc & ontin & & & & $10 \%$ \\
\hline $04 \mathrm{~A}$ & \multicolumn{9}{|c|}{ Monitoring not initiated until this date } & $\mathrm{U}$ & $\mathrm{O}$ & $\mathrm{U}$ & $\mathrm{U}$ & $\mathrm{U}$ & $\mathrm{U}$ & $\mathrm{U}$ & $\mathrm{U}$ & $13 \%$ \\
\hline 04B & \multirow{2}{*}{\multicolumn{9}{|c|}{$\begin{array}{l}\text { Monitoring not initiated until this date } \\
\text { Monitoring not initiated until this date }\end{array}$}} & $\mathrm{U}$ & $\mathrm{U}$ & $\mathrm{U}$ & $\mathrm{U}$ & $\mathrm{U}$ & $\mathrm{U}$ & $\mathrm{U}$ & $\mathrm{U}$ & $0 \%$ \\
\hline $04 \mathrm{C}$ & & & & & & & & & & $\mathrm{U}$ & $\mathrm{U}$ & $\mathrm{U}$ & $\mathrm{U}$ & $\mathrm{U}$ & $\mathrm{U}$ & $\mathrm{U}$ & $\mathrm{U}$ & $0 \%$ \\
\hline 5 & $\mathrm{U}$ & $\mathrm{U}$ & $\mathrm{U}$ & $\mathrm{U}$ & $\mathrm{U}$ & $\mathrm{U}$ & $\mathrm{U}$ & $\mathrm{U}$ & $\mathrm{U}$ & $\mathrm{U}$ & $\mathrm{U}$ & $\mathrm{U}$ & $\mathrm{U}$ & $\mathrm{U}$ & $\mathrm{U}$ & $\mathrm{U}$ & $\mathrm{U}$ & $0 \%$ \\
\hline 6 & $\mathrm{O}$ & $\mathrm{U}$ & $\mathrm{U}$ & $\mathrm{U}$ & $\mathrm{U}$ & $\mathrm{O}$ & $\mathrm{O}$ & $\mathrm{O}$ & $\mathrm{O}$ & $\mathrm{O}$ & $\mathrm{O}$ & $\mathrm{O}$ & $\mathrm{U}$ & $\mathrm{U}$ & $\mathrm{O}$ & $\mathrm{O}$ & $\mathrm{O}$ & $65 \%$ \\
\hline 7 & $\mathrm{O}$ & $\mathrm{U}$ & $\mathrm{U}$ & $\mathrm{U}$ & $\mathrm{U}$ & $\mathrm{U}$ & $\mathrm{U}$ & $\mathrm{U}$ & $\mathrm{U}$ & $\mathrm{U}$ & $\mathrm{U}$ & $\mathrm{U}$ & $\mathrm{U}$ & $\mathrm{O}$ & $\mathrm{O}$ & $\mathrm{O}$ & $\mathrm{O}$ & $29 \%$ \\
\hline 8 & $\mathrm{O}$ & $\mathrm{O}$ & $\mathrm{O}$ & $\mathrm{O}$ & $\mathrm{O}$ & $\mathrm{O}$ & $\mathrm{O}$ & $\mathrm{O}$ & $\mathrm{O}$ & $\mathrm{O}$ & $\mathrm{O}$ & $\mathrm{O}$ & $\mathrm{O}$ & $\mathrm{O}$ & $\mathrm{O}$ & $\mathrm{O}$ & $\mathrm{O}$ & $100 \%$ \\
\hline 08A & $\mathrm{U}$ & $\mathrm{U}$ & $\mathrm{U}$ & $\mathrm{U}$ & $\mathrm{U}$ & $\mathrm{U}$ & $\mathrm{U}$ & $\mathrm{U}$ & $\mathrm{U}$ & $\mathrm{U}$ & $\mathrm{U}$ & $\mathrm{U}$ & $\mathrm{U}$ & $\mathrm{U}$ & $\mathrm{U}$ & $\mathrm{U}$ & $\mathrm{U}$ & $0 \%$ \\
\hline 16 & $\mathrm{O}$ & $\mathrm{O}$ & $\mathrm{O}$ & $\mathrm{O}$ & $\mathrm{O}$ & $\mathrm{O}$ & $\mathrm{O}$ & $\mathrm{O}$ & $\mathrm{O}$ & $\mathrm{O}$ & $\mathrm{O}$ & $\mathrm{O}$ & $\mathrm{O}$ & $\mathrm{O}$ & $\mathrm{O}$ & $\mathrm{O}$ & $\mathrm{O}$ & $100 \%$ \\
\hline 17 & $\mathrm{O}$ & $\mathrm{U}$ & $\mathrm{O}$ & $\mathrm{O}$ & $\mathrm{O}$ & $\mathrm{U}$ & $\mathrm{U}$ & $\mathrm{O}$ & \multicolumn{9}{|c|}{ Monitoring discontinued beyond this date } & $63 \%$ \\
\hline $17 \mathrm{~A}$ & \multicolumn{8}{|c|}{ Monitoring not initiated until this date } & $\mathrm{O}$ & $\mathrm{O}$ & $\mathrm{U}$ & $\mathrm{O}$ & $\mathrm{U}$ & $\mathrm{O}$ & $\mathrm{U}$ & $\mathrm{U}$ & $\mathrm{O}$ & $56 \%$ \\
\hline 18 & $\mathrm{U}$ & $\mathrm{U}$ & $\mathrm{U}$ & $\mathrm{U}$ & $\mathrm{U}$ & $\mathrm{U}$ & $\mathrm{U}$ & $\mathrm{U}$ & $\mathrm{U}$ & $\mathrm{U}$ & $\mathrm{U}$ & $\mathrm{U}$ & $\mathrm{U}$ & $\mathrm{U}$ & $\mathrm{U}$ & $\mathrm{O}$ & $\mathrm{O}$ & $12 \%$ \\
\hline 22 & $\mathrm{O}$ & \multicolumn{16}{|c|}{ Monitoring discontinued beyond this date } & $100 \%$ \\
\hline 23 & $\mathrm{U}$ & $\mathrm{U}$ & $\mathrm{U}$ & $\mathrm{U}$ & $\mathrm{U}$ & $\mathrm{U}$ & $\mathrm{U}$ & $\mathrm{U}$ & $\mathrm{U}$ & $\mathrm{U}$ & $\mathrm{U}$ & $\mathrm{U}$ & $\mathrm{U}$ & $\mathrm{U}$ & $\mathrm{U}$ & $\mathrm{U}$ & $\mathrm{U}$ & $0 \%$ \\
\hline 24 & $\mathrm{U}$ & $\mathrm{U}$ & $\mathrm{U}$ & $\mathrm{U}$ & $\mathrm{U}$ & $\mathrm{U}$ & $\mathrm{U}$ & $\mathrm{U}$ & $\mathrm{U}$ & $\mathrm{U}$ & $\mathrm{U}$ & $\mathrm{U}$ & $\mathrm{U}$ & $\mathrm{U}$ & $\mathrm{U}$ & $\mathrm{U}$ & $\mathrm{U}$ & $0 \%$ \\
\hline 25 & $\mathrm{U}$ & $\mathrm{U}$ & $\mathrm{U}$ & $\mathrm{U}$ & $\mathrm{U}$ & $\mathrm{U}$ & $\mathrm{U}$ & $\mathrm{U}$ & $\mathrm{U}$ & $\mathrm{O}$ & $\mathrm{O}$ & $\mathrm{U}$ & $\mathrm{U}$ & $\mathrm{U}$ & $\mathrm{U}$ & $\mathrm{U}$ & $\mathrm{O}$ & $18 \%$ \\
\hline 26 & $\mathrm{O}$ & $\mathrm{U}$ & $\mathrm{U}$ & $\mathrm{U}$ & $\mathrm{O}$ & $\mathrm{O}$ & $\mathrm{O}$ & $\mathrm{O}$ & $\mathrm{O}$ & $\mathrm{O}$ & $\mathrm{O}$ & $\mathrm{O}$ & $\mathrm{O}$ & $\mathrm{O}$ & $\mathrm{O}$ & $\mathrm{O}$ & $\mathrm{O}$ & $82 \%$ \\
\hline 27 & $\mathrm{O}$ & $\mathrm{U}$ & $\mathrm{O}$ & $\mathrm{U}$ & $\mathrm{O}$ & $\mathrm{O}$ & $\mathrm{O}$ & $\mathrm{O}$ & $\mathrm{O}$ & $\mathrm{O}$ & $\mathrm{O}$ & $\mathrm{O}$ & $\mathrm{U}$ & $\mathrm{O}$ & $\mathrm{O}$ & $\mathrm{O}$ & $\mathrm{O}$ & $82 \%$ \\
\hline 28 & $\mathrm{O}$ & $\mathrm{U}$ & $\mathrm{U}$ & $\mathrm{U}$ & $\mathrm{U}$ & $\mathrm{U}$ & $\mathrm{U}$ & $\mathrm{U}$ & $\mathrm{O}$ & $\mathrm{O}$ & $\mathrm{O}$ & $\mathrm{U}$ & $\mathrm{U}$ & $\mathrm{U}$ & $\mathrm{U}$ & $\mathrm{O}$ & $\mathrm{O}$ & $35 \%$ \\
\hline 29 & $\mathrm{O}$ & $\mathrm{U}$ & $\mathrm{U}$ & $\mathrm{U}$ & $\mathrm{O}$ & $\mathrm{U}$ & $\mathrm{U}$ & $\mathrm{U}$ & $\mathrm{U}$ & $\mathrm{U}$ & $\mathrm{U}$ & $\mathrm{U}$ & $\mathrm{U}$ & $\mathrm{U}$ & $\mathrm{U}$ & $\mathrm{U}$ & $\mathrm{U}$ & $12 \%$ \\
\hline 30 & $\mathrm{U}$ & $\mathrm{U}$ & $\mathrm{U}$ & $\mathrm{U}$ & $\mathrm{U}$ & $\mathrm{U}$ & $\mathrm{U}$ & $\mathrm{U}$ & $\mathrm{U}$ & $\mathrm{U}$ & $\mathrm{U}$ & $\mathrm{U}$ & $\mathrm{U}$ & $\mathrm{U}$ & $\mathrm{U}$ & $\mathrm{U}$ & $\mathrm{U}$ & 0 \\
\hline 31 & \multicolumn{5}{|c|}{ Monitoring not initiated } & $\mathrm{U}$ & $\mathrm{U}$ & $\mathrm{U}$ & $\mathrm{U}$ & $\mathrm{O}$ & $\mathrm{O}$ & $\mathrm{U}$ & $\mathrm{U}$ & $\mathrm{U}$ & $\mathrm{U}$ & $\mathrm{O}$ & $\mathrm{O}$ & $33 \%$ \\
\hline 32 & \multicolumn{17}{|c|}{ Monitoring not initiated until this date } & $0 \%$ \\
\hline
\end{tabular}



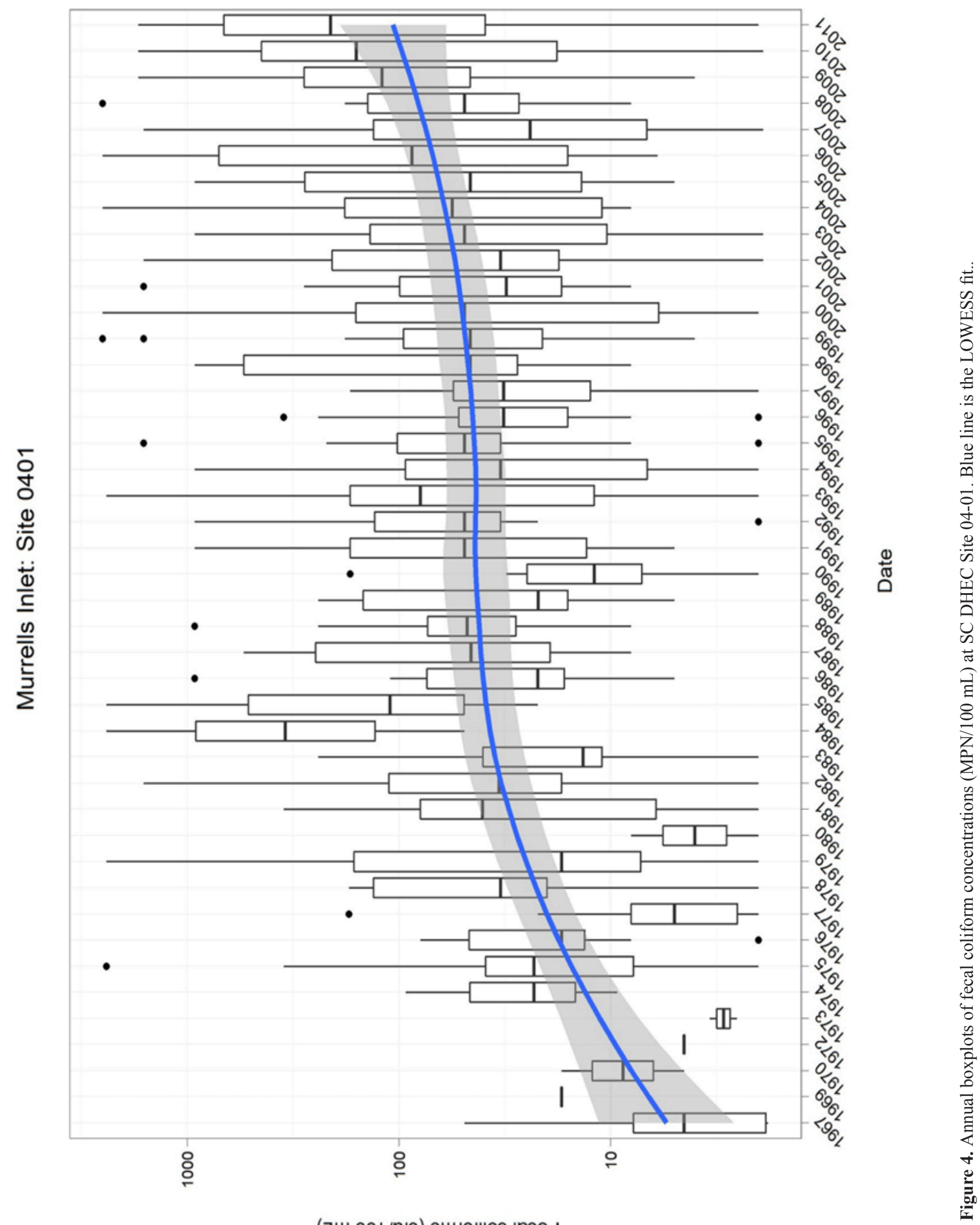

) 

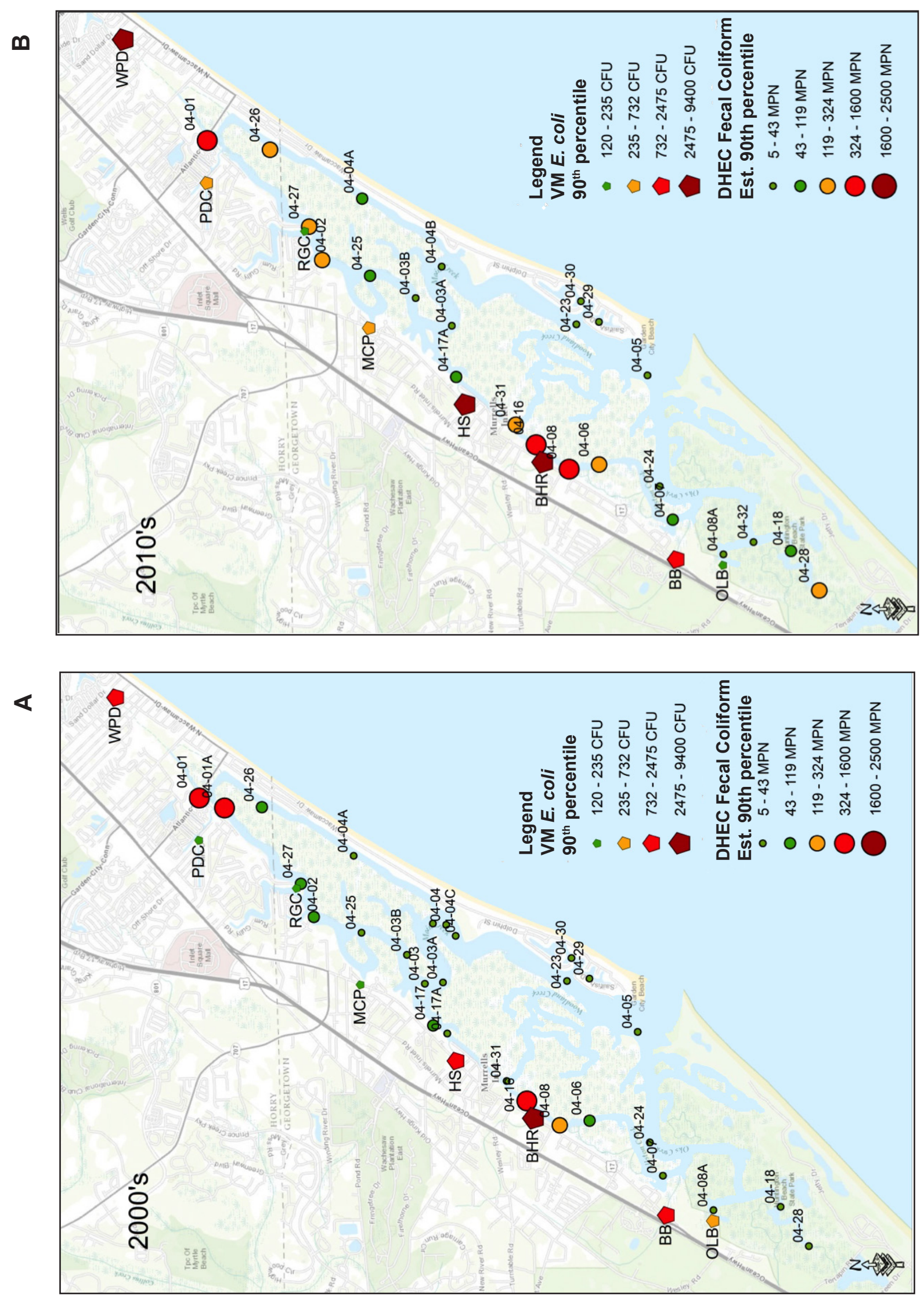

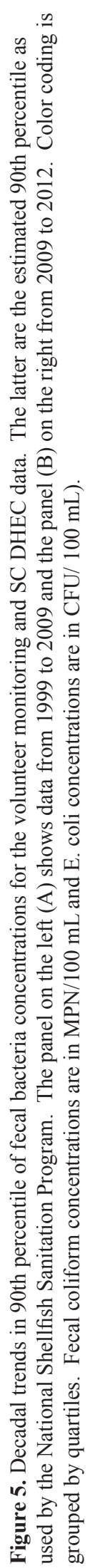


Table 5. (A) Percent exceedance of geomean and Est. 90th percentile in SC DHEC fecal coliform data from 1992 to 2011. Results are color coded from lowest to highest (green, yellow, organic, red). Sites that are no longer sampled are shaded yellow. Original TMDL sites are designated with an "o". Sites now within the TMDL are marked with an " $x$ " as per Table 1. Of these, sites 04-03A, 04-03B, 04-04A, 04-04C and 04-17A are located near marinas. Sites in red font are in Tiers 1 and 2 as per Figures 2 and 3. Site $04-32$ is a new site so no data were reported through 2011. (B) Quartiles of geomean and Est. 90 ${ }^{\text {th }}$ percentile in the fecal coliform data from all sites based on the most recent shellfish report (2009-2011). This color coding is used in Table 5A in the site column to identify which sites are currently most contaminated.

\begin{tabular}{|cc|c|c|}
\hline \multicolumn{2}{|c|}{ Sites } & Geomean & $\begin{array}{c}\text { Est. 90th } \\
\text { Percentile }\end{array}$ \\
\hline $04-01$ & 0 & $100 \%$ & $100 \%$ \\
\hline $04-01 a$ & 0 & $100 \%$ & $100 \%$ \\
\hline $04-02$ & 0 & $12 \%$ & $82 \%$ \\
\hline $04-03$ & & $0 \%$ & $0 \%$ \\
\hline $04-03 a$ & $x$ & $0 \%$ & $22 \%$ \\
\hline $04-03 b$ & $x$ & $0 \%$ & $22 \%$ \\
\hline $04-04$ & & $0 \%$ & $10 \%$ \\
\hline $04-04 a$ & $x$ & $0 \%$ & $13 \%$ \\
\hline $04-04 b$ & $0 \%$ & $0 \%$ \\
\hline $04-04 c$ & & $0 \%$ & $0 \%$ \\
\hline $04-05$ & & $0 \%$ & $0 \%$ \\
\hline $04-06$ & 0 & $12 \%$ & $65 \%$ \\
\hline $04-07$ & $x$ & $0 \%$ & $29 \%$ \\
\hline $04-08$ & 0 & $100 \%$ & $100 \%$ \\
\hline $04-08 a$ & $0 \%$ & $0 \%$ \\
\hline $04-16$ & 0 & $100 \%$ & $100 \%$ \\
\hline $04-17$ & & $13 \%$ & $63 \%$ \\
\hline $04-17 a$ & $x$ & $0 \%$ & $56 \%$ \\
\hline $04-18$ & $x$ & $0 \%$ & $12 \%$ \\
\hline $04-22$ & & \\
\hline $04-23$ & & $0 \%$ & $0 \%$ \\
\hline $04-24$ & & $0 \%$ & $0 \%$ \\
\hline $04-25$ & $x$ & $0 \%$ & $18 \%$ \\
\hline $04-26$ & 0 & $41 \%$ & $82 \%$ \\
\hline $04-27$ & 0 & $12 \%$ & $82 \%$ \\
\hline $04-28$ & $x$ & $6 \%$ & $35 \%$ \\
\hline $04-29$ & $x$ & $0 \%$ & $12 \%$ \\
\hline $04-30$ & $x$ & $0 \%$ & $0 \%$ \\
\hline $04-31$ & $x$ & $0 \%$ & $33 \%$ \\
\hline $04-32$ & & & \\
\hline & & & \\
\hline
\end{tabular}

\begin{tabular}{|c|c|c|}
\hline Percentile & Geomean & $\begin{array}{c}\text { Est. 90th } \\
\text { Percentile }\end{array}$ \\
\hline $90 \%$ & 52 & 324 \\
\hline $75 \%$ & 14 & 97 \\
\hline $50 \%$ & 8 & 43 \\
\hline $25 \%$ & 5 & 23 \\
\hline $10 \%$ & 4 & 19 \\
\hline
\end{tabular}

Table 6. Percent of sites exceeding the geomean and Est. $90^{\text {th }}$ percentile water quality criteria for each shellfish report issued between 1992 and 2011. Results are color coded from lowest to highest (green, yellow, organic, red). Shellfish reports with the highest percent exceedances are labeled in red font.

\begin{tabular}{|l|c|c|}
\hline Time period & Geomean & $\begin{array}{c}\text { Est. 90th } \\
\text { Percentile }\end{array}$ \\
\hline 1992 to 1994 & $23 \%$ & $59 \%$ \\
\hline 1994 to 1996 & $19 \%$ & $19 \%$ \\
\hline 1995 to 1997 & $19 \%$ & $29 \%$ \\
\hline 1996 to 1998 & $19 \%$ & $29 \%$ \\
\hline 1997 to 1999 & $19 \%$ & $43 \%$ \\
\hline 1998 to 2000 & $18 \%$ & $36 \%$ \\
\hline 1999 to 2001 & $18 \%$ & $32 \%$ \\
\hline 2000 to 2002 & $23 \%$ & $41 \%$ \\
\hline 2001 to 2003 & $18 \%$ & $50 \%$ \\
\hline 2002 to 2004 & $17 \%$ & $61 \%$ \\
\hline 2003 to 2005 & $17 \%$ & $46 \%$ \\
\hline 2004 to 2006 & $17 \%$ & $33 \%$ \\
\hline 2005 to 2007 & $13 \%$ & $21 \%$ \\
\hline 2006 to 2008 & $13 \%$ & $33 \%$ \\
\hline 2007 to 2009 & $13 \%$ & $33 \%$ \\
\hline 2008 to 2010 & $33 \%$ & $46 \%$ \\
\hline 2009 to 2011 & $28 \%$ & $52 \%$ \\
\hline
\end{tabular}


Table 7. $p$ values for Mann-Whitney U test for significant difference between dry and wet weather samples. Significant $p$ values are in red and less significant ones are in pink. Three windows of antecedent dry and wet weather were evaluated (1, 2 and 3 day). $\mathrm{W}=$ wet weather concentration $>$ dry weather concentrations. $\mathrm{D}=$ dry weather concentrations $>$ wet weather concentrations. Yellow cells had similar wet and dry concentrations. Black cells indicate no wet and/or dry data met the window selection criteria. See text for details on selection criteria. Site color coding is same as for Table 5.

\begin{tabular}{|c|c|c|c|c|c|c|c|}
\hline \multirow{2}{*}{\multicolumn{2}{|c|}{ Sites }} & \multicolumn{2}{|c|}{1 day } & \multicolumn{2}{|c|}{2 day } & \multicolumn{2}{|c|}{3 day } \\
\hline & & $p$ & higher & $p$ & higher & p & higher \\
\hline 04-01 & 0 & & & 0.02 & W & $<0.001$ & W \\
\hline 04-01a & 0 & & & 0.03 & W & 0.08 & W \\
\hline 04-02 & 0 & 0.04 & W & 0.00 & W & $<0.001$ & W \\
\hline \multicolumn{8}{|l|}{ 04-03 } \\
\hline 04-03a & $\mathbf{x}$ & & & & & & \\
\hline $04-03 b$ & $x$ & & & 0.09 & W & $<0.001$ & W \\
\hline 04-04 & & & & $<0.001$ & W & $<0.001$ & W \\
\hline 04-04a & $x$ & & & & & & \\
\hline $04-04 b$ & & & & 0.08 & & 0.03 & $D$ \\
\hline $04-04 c$ & & & & & & 0.01 & W \\
\hline \multicolumn{8}{|l|}{ 04-05 } \\
\hline 04-06 & 0 & & & & & 0.04 & W \\
\hline \multicolumn{8}{|l|}{ 04-07 } \\
\hline \multicolumn{8}{|l|}{ 04-08 } \\
\hline 04-08a & & & & 0.03 & W & 0.01 & W \\
\hline \multicolumn{8}{|l|}{ 04-16 } \\
\hline \multicolumn{8}{|l|}{ 04-17 } \\
\hline $04-17 a$ & $x$ & 0.01 & W & 0.00 & W & $<0.001$ & W \\
\hline $04-18$ & $\mathbf{x}$ & & & & & 0.06 & $\mathrm{~W}$ \\
\hline \multicolumn{8}{|l|}{$04-22$} \\
\hline \multicolumn{8}{|l|}{$04-23$} \\
\hline \multicolumn{8}{|l|}{ 04-24 } \\
\hline $04-25$ & $\mathbf{x}$ & & & $<0.001$ & $W$ & $<0.001$ & $\mathrm{~W}$ \\
\hline $04-26$ & 0 & & & $<0.001$ & W & $<0.001$ & W \\
\hline $04-27$ & 0 & 0.08 & $w$ & $<0.001$ & W & $<0.001$ & $W$ \\
\hline 04-28 & $x$ & & & & & & \\
\hline $04-29$ & $\mathbf{x}$ & & & 0.01 & W & 0.01 & $W$ \\
\hline $04-30$ & $x$ & & & 0.00 & W & $<0.001$ & W \\
\hline 04-31 & $x$ & & & 0.07 & W & 0.08 & $W$ \\
\hline $04-32$ & & & & & & & \\
\hline
\end{tabular}




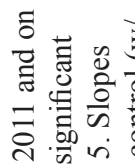

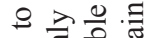

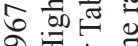

둥

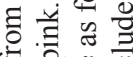

学宅

ब

(0)

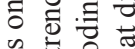

存

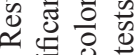

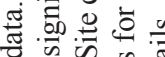

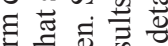

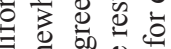

证

తु

踏.

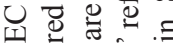

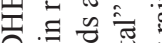

웡 훙

级

氜寻

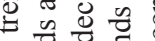

券苛

응

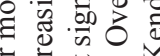

훙ㅎㅁ

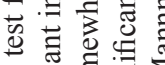

零

政

$\geq \tilde{0}$

言 항ㅎㅀ

$\sum$ 讨

수

둥.

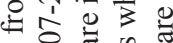

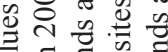

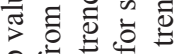

$\infty=$ on 0

o.

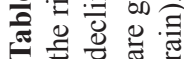

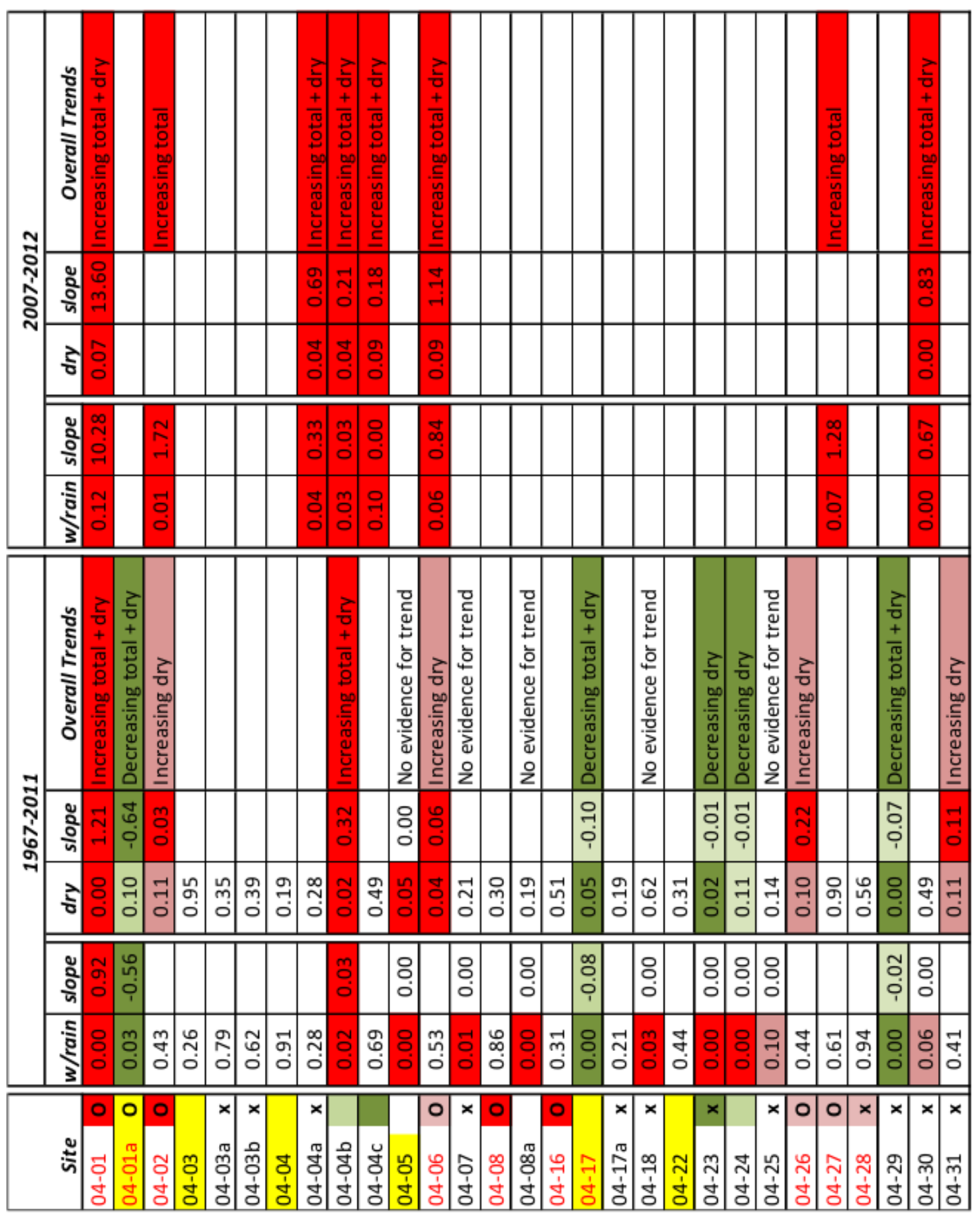


Effect of salinity. Figure 6 shows the linear regressions used to test for an inverse correlation of fecal coliform concentrations with salinity in the SC DHEC data from 1990 to 2011. The salinity data were binned into 9 categories as illustrated in the histogram shown in Figure 6A. The fecal coliform data were $\log$ transformed. The $\mathrm{p}$ value for the linear regression was highly significant $(p=0.0000)$ with a correlation coefficient of -0.62 , which suggests that as hypothesized, fecal coliform concentrations decrease with increasing salinity. This driver accounted for $62 \%$ of the variability in the fecal coliform concentrations.

Subwatershed prioritization. The results of all the statistical analyses were collated into the matrix presented in Table 10 to provide a weight-of-evidence approach to identification of subwatersheds with highest degrees of contamination or recent increasing trends. Three sets of subwatersheds were identified as problematic, i.e., the ones draining into Sites 04-01, 04-26 and 04-02 on the northernmost end of the Inlet, the ones draining into Sites 04-16, 04-08 and 04-06 on the mainland coastline at the middle of the Inlet, and the ones draining to Site 04-28 on the south end. The latter represents a site of recent shellfish bed closure, suggesting an increasing trend that could be most readily reversed by management intervention.

\section{DISCUSSION}

The results were collated in a map-based matrix that included subwatershed characteristics such as acreage and TR-55 estimated peak flows. This format was used to facilitate prioritization of subwatersheds for remediation via use of stormwater treatment practices. The spatial analyses illustrated that the sites located near commercial shellfish beds have high water quality, as they infrequently contravened water quality criteria. In contrast, most of the shellfish beds that are closed due to water quality impairments are on state grounds. The general driver behind these spatial trends is proximity to land with most of the approved beds being located in deeper portions of the estuary and the state grounds being located on the water frontage of the mainland.

In general, the highest fecal coliform levels are consistently observed at sites in tidal creeks with frontage on the mainland, suggesting a land-based source of the fecal bacteria. This was supported by statistical tests that found significantly higher fecal coliform levels under wet as compared to dry conditions at many sites and an inverse relationship with salinity. This also suggests that stormwater runoff from the land is an important transport agent. The inverse relationship with salinity likely arises from several related processes: (1) periods of lower salinity are associated with less dilution and flushing by seawater; (2) less die-off occurs in low salinity waters due to less contact with saline seawater; and (3) a greater likelihood of resuspension of sediment to which bacteria are adsorbed, following periods of stormwater runoff.
The sites with the highest levels of fecal coliform bacteria are located in the northern reach of the estuary, with statistically significant trends of increasing concentration. These sites are notable for reduced flushing caused by their distance from the mouth of the inlet and sedimentation infill that has reduced creek volumes. Statistical tests also found significantly higher fecal coliform concentrations during low tide at all sites. This further supports the role of reduced flushing in microbial contamination, although resuspension from marsh sediments at low tide could also be responsible.

The observations from the volunteer water quality monitoring program have identified two small tributaries as having consistently elevated $E$. coli levels during wet and dry conditions. Median concentrations at these sites are 1000 and $2000 \mathrm{CFU} / 100 \mathrm{~mL}(\mathrm{n}=123)$, respectively. This is similar to median $E$. coli concentrations reported in the National Stormwater Quality Database (NSQD) for overall types of land use, i.e., $1750 \mathrm{MPN} / 100 \mathrm{~mL}$ (Maestre and Pitt 2005). The SC DHEC shellfish monitoring sites located immediately downstream are also consistently elevated suggesting these tributaries are a possible conveyance of fecal bacteria from the land into the Inlet. The level of significance cannot be evaluated as no flow data are available for these small tributaries. One of these tributaries is located in a subwatershed that was identified during the watershed planning process as a priority for remediation based on the elevated bacteria levels reported by both monitoring programs.

The NSQD provides a type of benchmark for evaluating the degree of fecal coliform contamination in the waters of Murrells Inlet, i.e. median values in urban stormwater runoff are $5091 \mathrm{MPN} / 100 \mathrm{~mL}$ (Maestre and Pitt 2005). But because the upper limit of SC DHEC's reporting range is $1600 \mathrm{MPN} / 100 \mathrm{~mL}$, it is not possible to directly compare the NSQD results with levels in the receiving waters of Murrells Inlet. Another issue is that some of the SC DHEC monitoring data from the 1960s and 1970s could not be located for some of the sites.

\section{CONCLUSIONS}

Much evidence was identified supporting the importance of land-based sources of fecal bacteria to Murrells Inlet, especially during wet weather, although legacy sediment contamination in the tidal creek bottoms could also be a contributor. Evidence for increasing fecal coliform concentrations was found only at a few sites and could be associated with changes in rainfall, land use, and reduced flushing. The latter could be due to infill sedimentation in the tidal creeks. This process has a natural component to it as well as an anthropogenic influence as development mobilizes sediment from such processes as removal of vegetative buffers from stream and creek banks. Many of the near-shore sampling sites that exhibit the highest fecal coliform levels have been consistently exceeding the shellfish water quality criteria since at least the early 1980's and possibly earlier. 

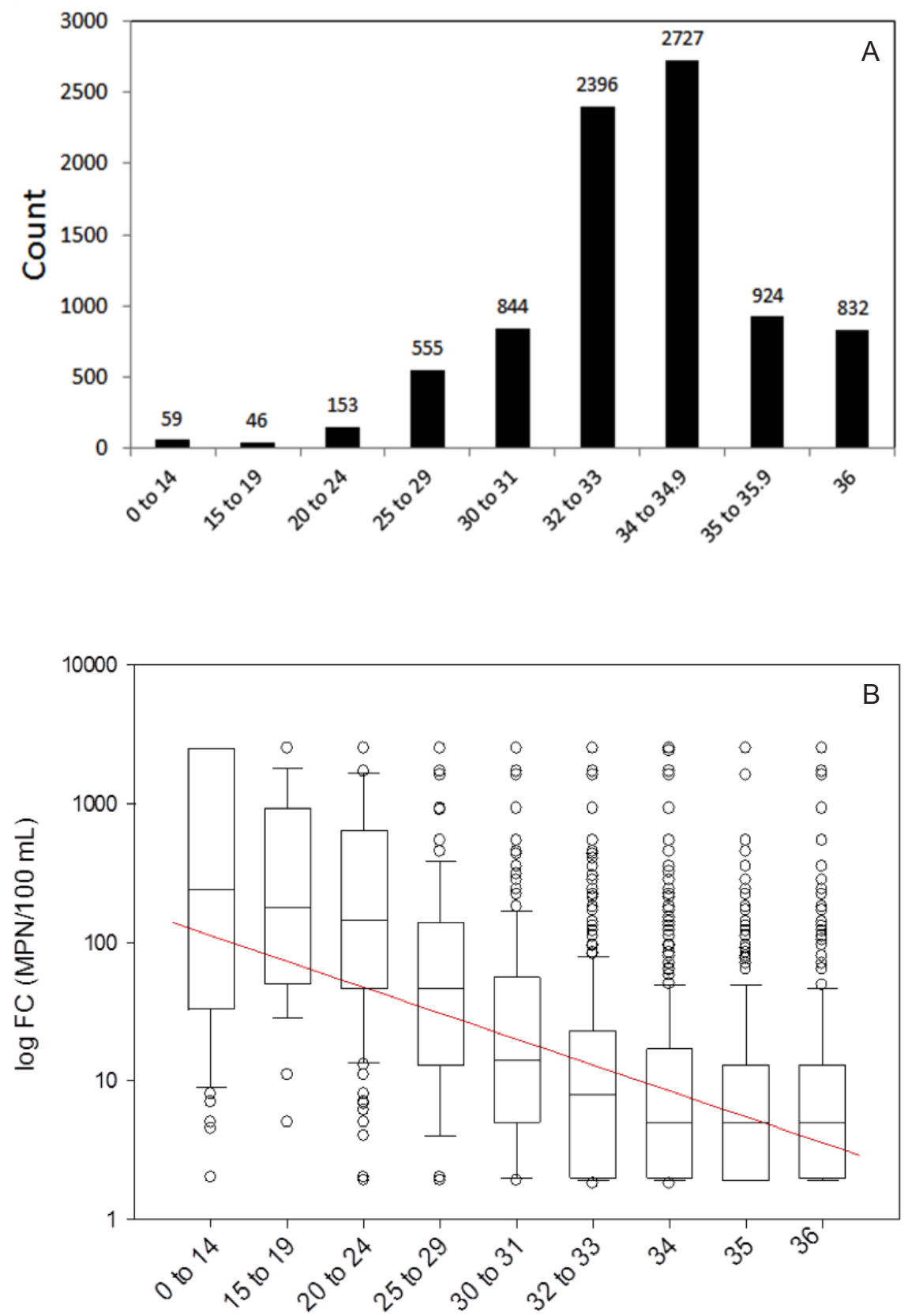

\section{Salinity}

Figure 6. Fecal coliform concentrations (MPN/100 mL) versus salinity (psu). (A) Sample counts in each salinity bin. (B) Linear regression of log-transformed fecal coliform against salinity using binning shown in panel (A). Data are shown as boxplots with $10^{\text {th }}$ and $90^{\text {th }}$ percentiles defining the hinges. Water quality criteria (geomean and Est. $90^{\text {th }}$ percentile are represented by the lower and upper orange lines, respectively. 
Watershed-Based Planning for Murrells Inlet

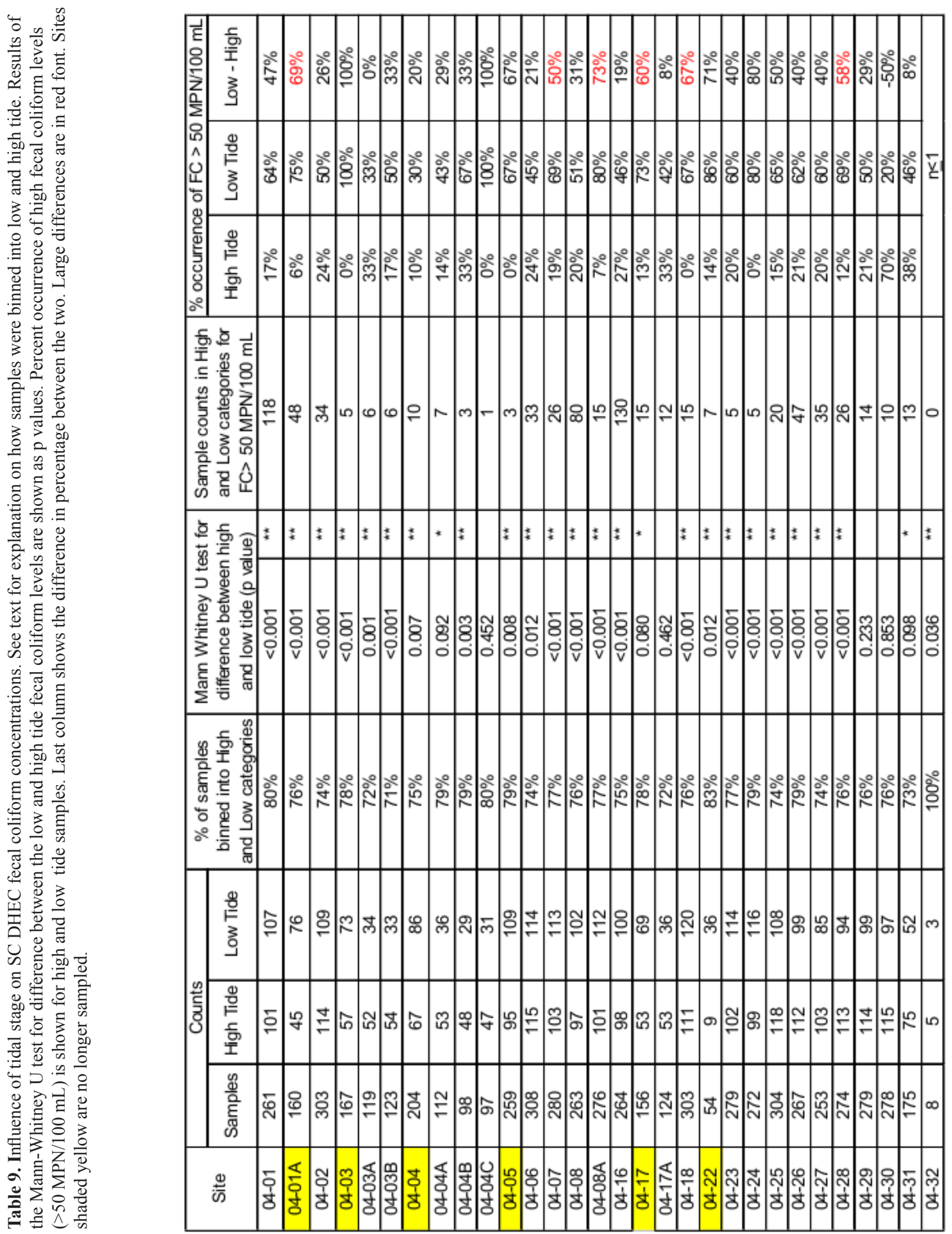




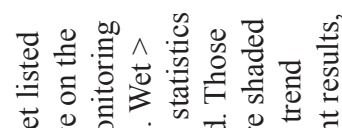

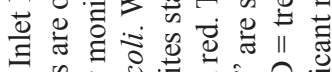

o:

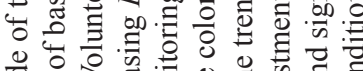

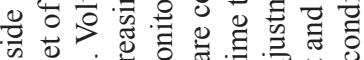

के

3 응ㅎㅁ

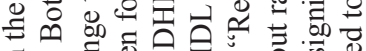

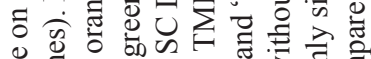

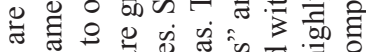

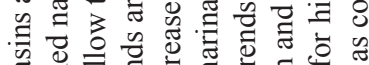

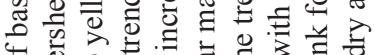

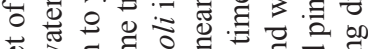

记

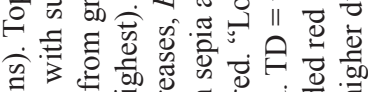

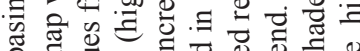

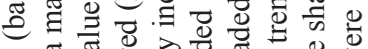

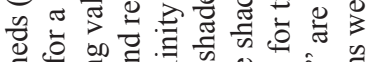

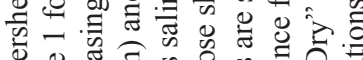

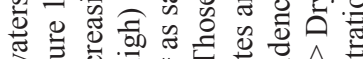

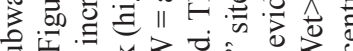

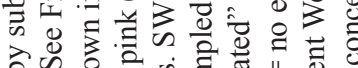

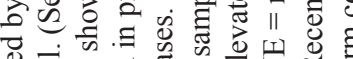

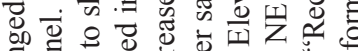

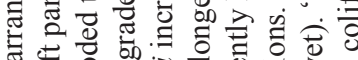

ब क्ष०

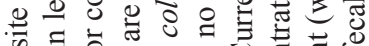

긍 कै

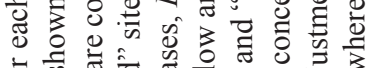

के की

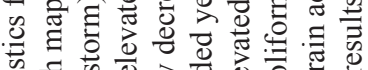

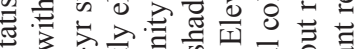

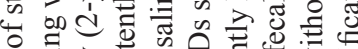

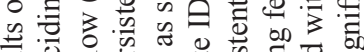

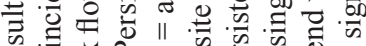

S.

की

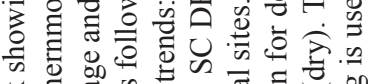

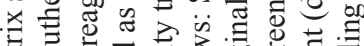

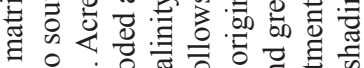

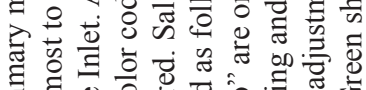

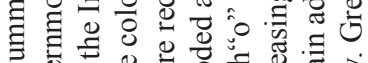

क 屯

$\dot{0}=0$

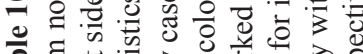

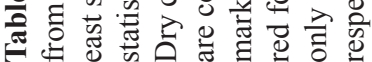
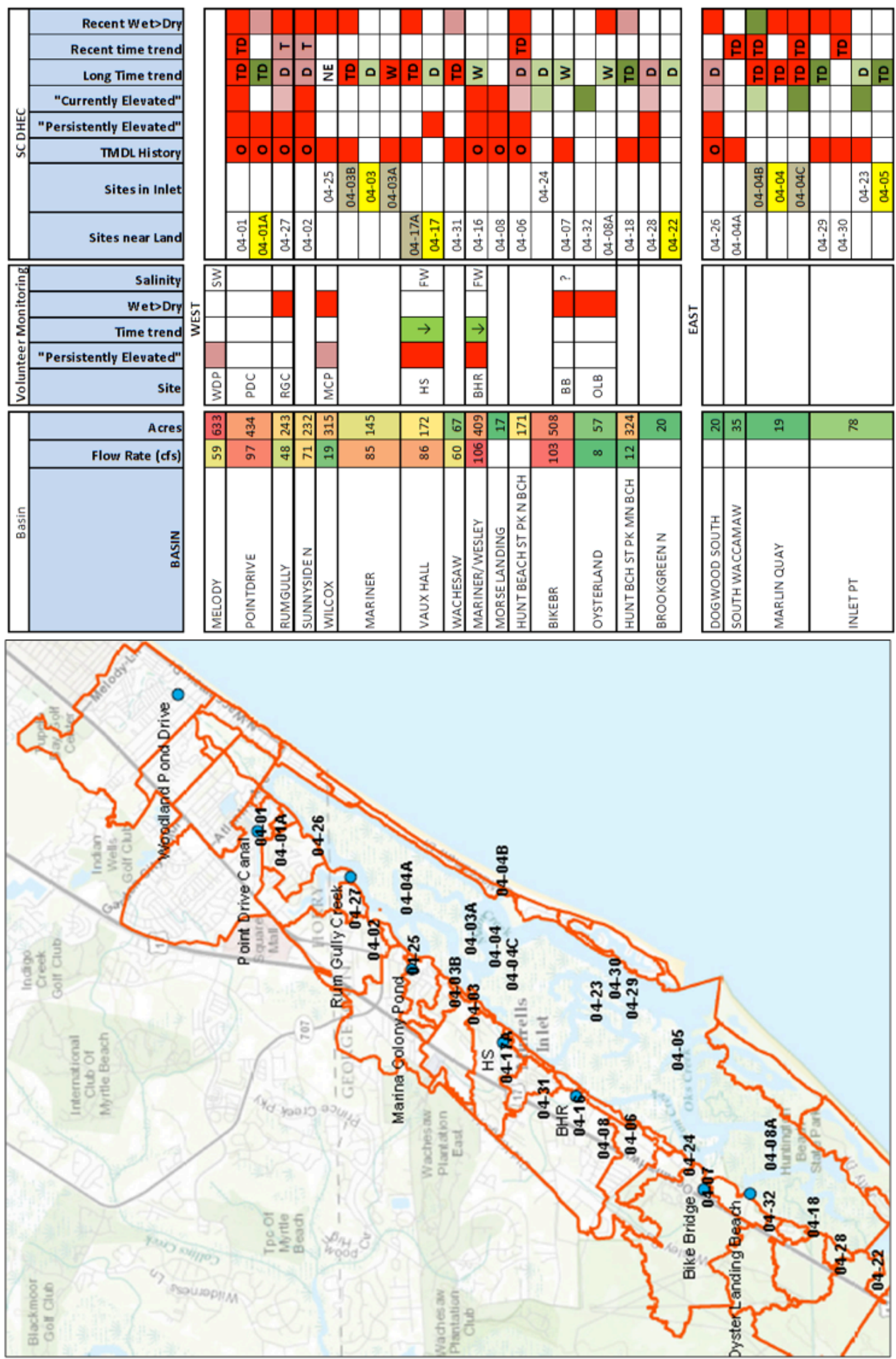
The most important bacterial sources identified were wildlife and canines. These conclusions were based, in part, on additional data collection conducted concurrently with the US EPA 319 project. These were funded by Georgetown and Horry Counties. They included efforts by the volunteers to track upstream sources (Young et al. 2014) and by CCU's Environmental Quality Lab to identify host animal sources using genotypic and chemical markers in the northern reaches of Murrells Inlet (Sturgeon et al. 2014). Genotypic source tracking efforts are pending for the middle and southern reaches.

The urbanized wildlife of greatest concern are raccoons and opossum. In urban settings, raccoons are known to reach extraordinarily high population densities due to lack of predators, abundant food supply, and their problem-solving abilities (Prange et al. 2003). The relative contribution of fecal indicator bacteria by urbanized wildlife has likely been enhanced by land-use changes associated with increased development as this leads to increased overland flows, and hence less infiltration of runoff and associated removal of microbes from the waters discharging into Murrells Inlet. This increase in overland flow arises from increased imperviousness and from the associated ditching and piping that have traditionally been used to manage increased stormwater flows and prevent flooding. These wildlife also are likely to frequent wetland areas to avoid human contact and as a water and food resource.

One of the most important outcomes of this collaborative data analysis was a better understanding of the SC DHEC shellfish monitoring data. This provided cautionary insight into how best to perform statistics and track general trends. For example, sample sites have been relocated over time to better define the boundaries of closed shellfish beds and thereby reduce the area subject to closure. In other words, the sampling sites are not representatively spaced through the Inlet. Over time, their locations have become concentrated in contaminated regions. A very large proportion are located near land, close to the most likely source(s) of the fecal bacteria. Without recognizing this sampling shifts, a cursory assessment of trend would indicate that water quality conditions have worsened.

Since only one fecal coliform sample is collected at each SC DHEC site per month, the potential exists for bias if rain days are over sampled. Efforts were made to check for this bias by comparing wet weather sampling frequency to rain frequency. No evidence was found to support bias over time scales of decades. The data did not support a higher resolution investigation. It is possible that rain could be causing a bias over short timescales. This could contribute to short timescale variability in fecal coliform levels with the result being short periods of bed closures. For example, beds were reopened in the southern portion of the Inlet in 2013 after first having been closed in 2011. SC DHEC attributed the improvement in water quality to diminished rainfall in 2011-2012. (The 2013 shellfish report was based on data from 2010 to 2012). Thus any climate phenomenon that contributes to rain variability has the potential to influence fecal coliform levels, such as the El Niño-Southern Oscillation that has a periodicity of 2 to 7 years (MacMynowski and Tziperman 2007).

The weight-of-evidence approach used in this study provided sufficient confirmatory evidence, despite the inherent limitations of the NSSP data, to identify priority subwatersheds for remediation. The transport processes elucidated from the fecal indicator data analysis lead to selection of a suite of best management practices (BMPs) that comprise some of the action items in the watershedbased plan (Newquist 2014). These BMPs are directed at intercepting stormwater flows, dredging in-filled creeks, and reducing fecal sources on land, recognizing that the populations of urbanized wildlife are not natural.

Approval of the watershed-based plan by SC DHEC enabled the stormwater managers in Horry and Georgetown County to obtain US EPA 319 funding to implement some of these BMPs. Insights from the collaborative data analysis also lead to formulation of action items that recommend monitoring that is enhanced to better assess progress in remediating fecal coliform impairments in Murrells Inlet.

\section{ACKNOWLEDGEMENTS}

Technical support was provided by SC DHEC (M. Murphy, A. Bennett and M. Pearson), US EPA Region IV (K. Synder), Georgetown County Stormwater (T. Jones), Horry County Stormwater (D. Fuss and T. Garigen), and Earthworks, Inc. (S. Williams). Funding was provided by SCDHEC, Horry and Georgetown Counties.

\section{LITERATURE CITED}

Anderson, J. A., and L. M. Gresoki, 2010. Microbial Source Tracking of E. coli and Total Coliforms in Murrells Inlet, SC. Prepared for Georgetown County, South Carolina, 25 pp. http://www.coastal.edu/media/academics/ collegeofscience/centers/waccamawwatershedacademy/ pdfs/MST_MI_051811.pdf.

Bennett. J., 2007. Final Report for Field and Analytical Services to Assess the Effectiveness of Stormwater Best Management Practices in the Receiving Waters of Murrells Inlet. South Carolina Department of Health and Environmental Control, Contract \#581336, 28 pp. http://www.coastal.edu/media/academics/collegeofscience/ centers/waccamawwatershedacademy/pdfs/MI $\% 20$ SAMP\%20BMPs\%20Pjt\%20Final\%20Rpt_Aug07.pdf.

Fuss, D., D. Newquist, S. Sledz, T. Jones, and D. Hitchcock, 2014. Watershed Plan Implementation Challenges for SMS4s in Murrells Inlet. Proceedings of the 2014 South Carolina Water Resources Conference, held October 15-16, 2014 at the Columbia Metropolitan Convention Center.

Helsel, D. R., D. K. Mueller, and J. R. Slack, 2006. Computer program for the Kendall family of trend tests: U.S. Geological Survey Scientific Investigations Report 2005-5275, 4 p. http://pubs.usgs.gov/sir/2005/5275/. 
Hirsch, R. M., and J. R. Slack, 1984. A Nonparametric Trend Test for Seasonal Data with Serial Dependence. Water Resources Research, 20: 727-732.

Kelsey, H., D. E. Porter, G. Scott, M. Neet, and D. White, 2004. Using geographic information systems and regression analysis to evaluate relationships between land use and fecal coliform bacterial pollution. Journal of Exper. Mar. Biol. Ecol., V.298:197-209.

Kelsey, H., G. I. Scott, D. E. Porter, B. Thompson, and L. Webster, 2003. Using Multiple Antibiotic Resistance and Land Use Characteristics to Determine Sources of Fecal Coliform Bacterial Pollution. Environmental Monitoring and Assessment, 81:337-348.

Libes, S., K. Hayes, and C. Ellis, 2012. Volunteer Water Quality Monitoring in Northeastern South Carolina for NPDES Phase II Stormwater Compliance. Proceedings of the 2012 SC Environmental Conference, held on March 10-14, 2012 at the Myrtle Beach Convention Center. http://www.coastal.edu/media/academics/ collegeofscience/centers/waccamawwatershedacademy/ pdfs/Libes\%20et\%20al\%202012\%20VM\%20 Monitoring\%20in\%20SC.pdf.

MacMynowski, D. G., and E. Tziperman, 2007. Factors Affecting ENSO's Period. Journal of the Atmospheric Sciences, 65:1570-1586.

Maestre, A., and R. Pitt, 2005. The National Stormwater Quality Database, Version 1.1: A Compilation and Analysis of NPDES Stormwater Monitoring Information. US EPA Office Water, Washington, DC. http://rpitt.eng. ua.edu/Publications/Stormwater\%20Characteristics/ NSQD\%20EPA.pdf.

Newquist, D., 2014. 2014 Murrells Inlet Watershedbased Plan: A Community-Based Management Plan to Address Fecal Coliform Impairments in Local Shellfish Harvesting Areas. Waccamaw Council of Governments, Georgetown, South Carolina. http:/wrcog.org/ transportation-planning/air-quality-coalition/.

Newquist, D., S. Sledz, S. Libes, S. Williams, D. Fuss, T. Jones, and D. Hitchcock, 2014. Murrells Inlet Watershed: Positive Outcomes from a Multistakeholder Planning Process. Proceedings of the 2014 South Carolina Water Resources Conference, held October 15-16, 2014 at the Columbia Metropolitan Convention Center.

Prange, S., S. D. Gehrt, and E. P. Wiggers, 2003.

Demographic Factors Contributing to High Raccoon Densities in Urban Landscapes. Journal of Wildlife Management, 67:324-333.

Sturgeon, A., S. Libes, E. Burge, and M. Trapp, 2014. Building local capacity for microbial source tracking in the Myrtle Beach Urbanized Area. Proceedings of the 2014 South Carolina Water Resources Conference, held October 15-16, 2014 at the Columbia Metropolitan Convention Center.
South Carolina Department of Health and Environmental Control, 2014. Shellfish Management Area 042014 Annual Update. South Carolina Department of Health and Environmental Control, Shellfish Sanitation Section, Water Monitoring, Assessment and Protection Division, Columbia, South Carolina http://www.scdhec.net/ environment/water/shellfish.htm.

South Carolina Department of Health and Environmental Control, 2005. Total Maximum Daily Loads for Fecal Coliform in Shellfish Waters of the Murrells Inlet Estuary, South Carolina. SC DHEC, Columbia, SC. http://www.scdhec.gov/ HomeAndEnvironment/Docs/tmdl_murrells_fc.pdf. United States Environmental Protection Agency, 2008. Draft Handbook for Developing Watershed TMDLs. Office of Wetlands, Oceans \& Watersheds. http:// water.epa.gov/lawsregs/lawsguidance/cwa/tmdl/ upload/2009_01_09_tmdl_draft_handbook.pdf.

United States Food and Drug Administration, 2009. 2009 National Shellfish Sanitation Program Guide for the Control of Molluscan Shellfish. http://www. fda.gov/downloads/Food/GuidanceRegulation/ FederalStateFoodPrograms/UCM350004.pdf.

Williams, S. G., D. Newquist, S. Libes, and S. G. Strickland, 2014. Watershed Management Planning for the Murrells Inlet Estuary using GIS: Delineation, Assessment, Identification, and Solutions for Fecal Coliform Loading. Proceedings of the 2014 South Carolina Water Resources Conference, held October 15-16, 2014 at the Columbia Metropolitan Convention Center.

Young, H., S. Libes, D. Newquist, D. Fuss, and T. Jones, 2014. Water quality stewardship informs management directions. Proceedings of the 2014 South Carolina Water Resources Conference, held October 15-16, 2014 at the Columbia Metropolitan Convention Center. 